Article type : Original Article

\title{
New Plate Kinematic Model and Tectono-stratigraphic History of the East African and West Madagascan Margins
}

\author{
A. Tuck-Martin ${ }^{1}$, J. Adam ${ }^{1}$, and G. Eagles ${ }^{2}$ \\ ${ }^{1}$ Department of Earth Sciences, Royal Holloway, University of London, Egham, Surrey, UK \\ ${ }^{2}$ Alfred Wegner Institute, Helmholtz Centre for Polar und Marine Research, Bremerhaven, Germany. \\ Corresponding author: Amy Tuck-Martin (Amy.Tuck-Martin.2010@live.rhul.ac.uk)
}

\begin{abstract}
The continental margins of East Africa (EA) and West Madagascar (MAD) are a frontier for hydrocarbon exploration. However, the links between the regional tectonic history of sedimentary basins and margin evolution are relatively poorly understood. We use a plate kinematic model built by joint inversion of seafloor spreading data as a starting point to analyse the evolution of conjugate margin segments and corresponding sedimentary basins. By correlating megasequences in the basins to the plate model we produce a margin-scale tectono-stratigraphic framework comprising four phases of tectonic development. During Phase 1 (183-133 Ma) Madagascar/India/Antarctica separated from Africa, first by rifting and later, after breakup (at 170-165 Ma), by seafloor spreading in the West Somali and Mozambique basins and dextral strike-slip movement on the Davie Fracture Zone. Mixed continental/marine syn-rift megasequences were deposited in rift basins followed by shallow-marine early post-rift sequences. In Phase 2 (133-89 Ma) spreading ceased in the West Somali basin and Madagascar became fixed to the African plate. However, spreading continued between the African and Antarctic plates and deposition of the early post-rift megasequence continued. The onset of spreading on the Mascarene Ridge separated India from Madagascar in Phase 3 (89-60 Ma). Phase 3 was characterised by the onset of deposition of the late post-rift megasequence with continued deep marine sedimentation. At the onset of Phase 4 (60 Ma onward) spreading on the Mascarene ridge ceased and the Carlsberg Ridge propagated south to form the Central Indian Ridge, separating India from the Seychelles and the Mascarene Plateau. Late post-rift deposition continued until a major unconformity linked to the development of the East African Rift System marked the change to deposition of the modern margin megasequence.
\end{abstract}

Key Words: Tectonics, plate kinematics, rifted continental margins, East Africa, West Madagascar, megasequences, tectono-stratigraphy

\section{Introduction}

Hydrocarbon exploration along the East African margin has been going on for the past 50-60 years but it has been slow and intermittent, hampered by political instabilities and disappointing results. In the last two decades there has been a resurgence in exploration, spurred on by significant gas discoveries, for example the Pweza deep-water gas discovery offshore Tanzania. Despite the recent

This article has been accepted for publication and undergone full peer review but has not been through the copyediting, typesetting, pagination and proofreading process, which may lead to differences between this version and the Version of Record. Please cite this article as doi: 10.1111/bre.12294

This article is protected by copyright. All rights reserved. 
boom in interest, the East African margin remains underexplored and its geodynamic and geological evolution poorly understood. We aim to develop an integrated margin-wide chronostratigraphy based on the correlation of plate kinematic processes with the regional tectonic events which can be used as potential framework for margin-scale tectonostratigraphic correlations of the basin fill histories of the sedimentary basins (Fig. 1). To do this, we present a new high-resolution plate kinematic model of the Northwest Indian Ocean, interpret it in terms of geodynamic changes, and consider the implications these changes are likely to have had on the development of tectonically controlled megasequences in sedimentary basins along the East African and West Madagascan Margins.

The tectonic evolution of the Northwest Indian Ocean and the present-day configuration of its accompanying continental margins (Fig. 1) have been complicated by a number of major tectonic changes. Continents embedded within the region's plates, most importantly Africa, Madagascar, India, and Antarctica, formed parts of Gondwana, the southern portion of the supercontinent Pangea, from approx. 300 to $180 \mathrm{Ma}$. Throughout this time, episodic intracontinental rifting propagated through southern and eastern Africa, possibly reaching as far north as Somalia, and Madagascar (Catuneau et al., 2005). These rifting events, often grouped as a 'Karoo' rifting phase, culminated in the eruption of the Karoo-Ferrar Large Igneous Province (LIP) across South Africa (Karoo) and Antarctica (Ferrar) (Cox, 1992). Further rifting and breakup followed in the Jurassic as East Gondwana (Madagascar/India/Seychelles/Australia/Antarctica) separated from West Gondwana (Africa, South America). The timing of this breakup is widely disputed and will be addressed in this paper. Following the initial breakup, East Gondwana continued to fragment forming the present-day plate assembly (Fig. 1).

As an emerging frontier for oil and gas exploration, the East African and West Madagascan Margins need to be understood in terms of their tectonic and basin fill histories, in particular how rifting, break-up and post-rift phases and related petroleum systems elements can be correlated along the margins. Currently, no satisfactory and coherent plate tectonic model exists to piece together all the tectonic events and changes in the area.

This paper presents results of a new high-resolution plate rotation model for the separation of East Antarctica and Africa. The new model is an update to the study of Eagles \& König (2008) incorporating new data and interpretations from the West Somali and Mozambique basins and RiiserLarsen Sea (Leinweber \& Jokat, 2012; Sandwell et al., 2014; Davis et al., 2016; Phethean et al., 2016). The new Africa-Antarctica rotations are combined with previously-published rotations for the other pairs of plates in the region generated by a mixture of visual fitting and iterative joint inversions of magnetic isochron and fracture zone data, which allow to model the progressive development of the ocean basins in between continental fragments and to build a plate kinematic model consisting of multiple reconstruction maps.

The tectono-stratigraphic history of the rifted continental margin sedimentary basins along the East African and West Madagascan margins can be correlated and analysed by reference to the plate kinematic model. Here, we investigate the effects of these changes on the tectonically controlled megasequences of following conjugate margin segments: East Africa-India (EA-IND), East AfricaMadagascar (EA-MAD), Madagascar-East Africa (MAD-EA) and East Africa-Antarctica (EA-ANT). We have reviewed regional stratigraphy and structural information from basins on the conjugate margin segments, identifying important regional unconformities and megasequences, and integrated this information with the plate kinematic model to enable correlations along margin segments and between conjugate margin segments. The result is a margin-scale chronostratigraphic correlation chart documenting the evolution of the East African margin and its sedimentary basins. Ongoing work will

This article is protected by copyright. All rights reserved. 
provide an in-depth review of individual basins to better understand their regional tectonic and basinfill history as well as the timing and distribution of petroleum system types (Tuck-Martin et al., 2016, 2015)

\subsection{Previous Work}

The first conjugate magnetic anomaly isochrons in the study region were identified in the late 1960's in the Arabian and East Somali Basins (Royer et al., 2002). Over the years, many more have been identified and refined (McKenzie \& Sclater, 1971; Norton \& Sclater, 1979; Schlich, 1982; Patriat \& Segoufin, 1988; Cande et al., 2010; König \& Jokat, 2010; Leinweber \& Jokat, 2012). On the basis of this growing data set, regional scale complexities in the formation of the Indian Ocean have been recognised, including the asymmetric accretion of oceanic crust to the African and Indian plates at different times, the action of propagating ridges, independent motion of the Seychelles plate and Miocene and younger regional deformation of the broad plate boundary zones surrounding the Capricorn plate. Accordingly, early reconstructions of the magnetic isochrons did not fully recognise these problems, and their accuracy suffered accordingly (e.g. Molnar et al., 1988). The arrival of freeair gravity anomaly maps derived from satellite altimetry in the 1980's and their subsequent improvement (see supplementary materials to Sandwell et al., 2014) give a uniform and highresolution view of the structure of the ocean floor to complement the magnetic isochron data set. These data have helped more recent reconstructions to work in different ways to overcome the obstacles to a coherent tectonic reconstruction of the area.

Many of these recent reconstructions maintain a focus on magnetic isochron picks because of their use of the inversion method of Hellinger (1981) to calculate rotation parameters for making best fits of conjugate magnetic isochrons on the sea floor. The most up-to-date models of such reconstructions are those of Cande et al. (2010) and Cande and Patriat (2015). The authors used data from the Carlsberg (CR), Central Indian (CIR), Southwest Indian (SWIR) and Southeast Indian ridges (SEIR) in different combinations to calculate four sets of Euler rotations for motions between the India (Capricorn), Africa (Somali) and Antarctic plates. They found that many of the data could be combined in a closed plate circuit, but that closure prior to chron 22o (49.427 Ma) locally required some degree of plate convergence within the African plate, which they related to anti-clockwise rotation of a small plate bearing the Seychelles with a convergent boundary at the Amirante Trench (Fig. 1).

Other recent studies (e.g. Eagles and Hoang, 2013) in the region have applied the alternative reconstruction technique of Nankivell (1997) to similar magnetic data sets together with a more rigorous treatment of the plate motion information contained in the shapes of fracture zones, evident in gravity anomaly data over regions of oceanic crust. These studies depict the separations of the African and Antarctic, African and Indian, and African and Seychelles plates without attempting to close the plate circuit, which is sensitive to the more coarsely-estimated motion of the Capricorn plate (DeMets et al., 2005). The kinematic history depicted in the NW Indian Ocean is smoother than that of Cande et al (2010) and Cande and Patriat (2015), and portrays a higher-resolution evolution of the Seychelles-Africa plate boundary. In the SW Indian Ocean, however, the technique has only been applied to pre-mid Cretaceous data (Eagles and König, 2008), and pre-dates the collection of new and better data in key locations (König and Jokat, 2010; Phethean et al., 2016).

This article is protected by copyright. All rights reserved. 


\section{Method}

The joint inversion technique of Nankivell (1997), as described by Eagles (2004) and Livermore et al. (2005), produces finite rotation poles and angles of rotation about them by minimizing the misfits of sets of small and great circle segments to the locations of fracture zones and isochron data in the ocean floor produced by the divergence of pairs of plates. Using this method, a full new model for Antarctica - Africa divergence since Jurassic times is described below in section 2.1. The intention is to provide a quantitative and up-to-date model of seafloor spreading data to combine with the similarly-derived models of Eagles \& Wibisono (2013) and Eagles \& Hoang (2013) (sections 2.2 and 2.3), and so provide a methodologically-consistent basis on which to interpret the plate kinematic history from 183 Ma to the present day.

\subsection{New rotation model for ANT-AFR plate motion}

Figure 2 presents the data set for modelling of new Euler rotations describing the separation of Africa from Antarctica since Jurassic times. This data set extends that of Eagles and König (2008), whose model did not address the most recent 100 million years of plate divergence, and revises its oldest parts on the basis that its M-Series anomaly picks in the Mozambique and West Somali basins have been shown to be unlikely. In the Mozambique Basin, our revision straightforwardly follows the interpretation of recently-acquired magnetic data (König and Jokat, 2010; Leinweber and Jokat, 2012). In the West Somali Basin, the picks required reinterpretation because of recent improvements in gravity imaging of a subtly-expressed extinct mid-ocean ridge (Phethean et al., 2016). Davis et al. (2016) show that this new constraint can be consistent with existing models (e.g. Segoufin and Patriat, 1980; Cochran, 1988) of a sequence of seafloor spreading isochrons in the basin that ends shortly after the onset of the Cretaceous normal polarity superchron. In Figure 3, we show that the extinct ridge location is also consistent with alternative interpretations of that sequence as ending close to isochron M10n, around 12 Myr earlier (Rabinowitz et al., 1983; Eagles and König, 2008). The ultimate reason for the ongoing uncertainty regarding these two alternative interpretations is that detailed waveform correlations between available magnetic anomaly profiles in the basin are not possible. Following Eagles and König (2008), we prefer the interpretation of extinction around M10n for two reasons: (i) that it requires relative motions between just two large plates and no unattested motion of a Madagascar plate, and (ii) that its intermediate ( $\sim 2 \mathrm{~km} / \mathrm{Myr})$ full seafloor spreading rates at extinction are more consistent with the rather subdued appearance of the abandoned ridge crest in gravity anomaly data than the slow $(\sim 26 \mathrm{~km} / \mathrm{Myr})$ rates at extinction in the alternative interpretation. In contrast, Davis et al. (2016) preferred a later extinction date because it enables reconstructions that (i) preserve correlations of interpreted pre-fit markers between Africa and Madagascar and (ii) do not require large follow-on adjustments to the modelled geometry of the remainder of East Gondwana. The problem of the timing of seafloor spreading in the West Somali basin thus seems set to remain finely balanced until new and more reliable magnetic data become available.

The coloured symbols in figure 2 represent the locations of magnetic isochrons as identified by Nankivell (1997) and Eagles and König (2008), updated for the large new data set of König and Jokat (2010), and reinterpreted in the West Somali Basin as described above. Rows of small black triangles denote our picks of fracture zone locations derived from the vertical gradient in the most recent version of Sandwell et al.'s (2014) satellite gravity data set (fig. 2a). The new data set makes the locations of fracture zones in the oldest parts of the seafloor in the Mozambique basin and Riiser Larsen Sea clearer than the data set available to Eagles and König (2008). In addition, in the West Somali Basin we used the directionally-filtered gravity anomalies of Phethean et al. (2016) to help

This article is protected by copyright. All rights reserved. 
guide our fracture zone interpretations. For the plate-kinematic model presented here, we have made no attempt to reduce the data set to reflect the Neogene relative motion of Somalian and Nubian component plates of Africa (Horner-Johnson et al., 2007).

The data set was modelled by least squares minimization of the misfits between rotated magnetic isochron picks and their conjugate and non-conjugate neighbours within shared corridors and of the misfits of synthetic ridge-crest offset flowlines to the fracture zone locations. Figure 2 represents this process by showing the rotated magnetic isochrons as grey outline symbols, and the synthetic flowlines in blue. The advantage in using non-conjugate target figures is that it permits us to include data from the African flank of the West Somali basin, as well as numerous data in less well-populated corridors, enabling a useful solution for continuous plate motion since late Jurassic times to be calculated. The disadvantage of this approach is that the use of sparse data and data without conjugates is likely to introduce populations of larger misfits into the model such that its quality in some locations or for some times is less than can be achieved by targeted modelling of the denser data set for younger periods (Horner-Johnson et al., 2007). Cande and Patriat (2015) show that this precision is of local rather than regional importance for studies of this geographical and temporal scale.

A stable solution like the one presented in figure 2 can be generated after a few tens of iterations regardless of whether it is approached from a set of initial test rotations like those of Eagles and König (2008) or those of Leinweber and Jokat (2012). The mean of all misfits for the magnetic isochron picks is $1.1 \mathrm{~km}$ and their standard deviation is $18.6 \mathrm{~km}$. For fracture zone picks, the mean is $0.4 \mathrm{~km}$ and the standard deviation is $8.8 \mathrm{~km}$. The best fitting Gaussian approximation to the isochron misfit population has mean and standard deviation of 0.2 and $14.5 \mathrm{~km}$, and that to the fracture zone misfits has 1.0 and $6.9 \mathrm{~km}$. These values are within expected ranges for a data set and model geometry like this, comparable to a priori estimates of locational uncertainty in isochron and fracture zone picks, but mostly too large to enable the model to reliably resolve the small differences between the motions of the Somali and Nubian plates with respect to the Antarctic plate (Horner-Johnson et al., 2007). The geographical distribution of the misfits does not suggest that these data describe largerscale motion of any large plate other than those bearing Africa and Antarctica.

Figure 2(b) shows the locations of the finite reconstruction poles and 2-dimensional 95\% confidence ellipses for them, calculated using the best-fit Gaussian misfit statistics above as estimates of the overall locational uncertainties. The full set of parameters is listed in Table 1. The rotation poles for Africa with respect to Antarctica are almost coincident at the 95\% confidence level in the period between M22 $\mathrm{n}$ and the end of spreading in the West Somali Basin (155-133 Ma; rotation WSB); the instantaneous rotation pole may have been essentially stationary throughout this period. This circumstance is consistent with a two-plate system whose relative motions were governed by an equilibrated set of driving forces. The locations of the rotation poles between M9n and ma96 (133-96 $\mathrm{Ma}$ ), on the other hand, are statistically distinguishable from one another at $95 \%$ level, and migrate consistently towards the SSW. This coincides with an increase in the relative plate divergence velocity (figure 2(c)). The onset of this epoch coincides with the loss of data from the West Somali Basin, which we assume to have ceased opening by seafloor spreading shortly before M9n. Pole locations begin to migrate towards the NW after ma96, again with statistical significance until chron $33 \mathrm{y}$, and the plate divergence rate begins slowing again. This may reflect the effects of regional plate boundary reorganisations brought about by arrivals of the Bouvet and/or Marion plumes in the South Atlantic and beneath Madagascar. Slowing rates accompany a stationary pole of rotation, within error, until chron 30y, the time of arrival of the Deccan plume beneath what was to become the India-Africa plate boundary. A new kinematic epoch is suggested by the southwards migration of finite rotation

This article is protected by copyright. All rights reserved. 
poles between chrons $30 \mathrm{y}-28 \mathrm{o}$ and $13 \mathrm{y}$. This period might be broken down into an earlier period of rapid change in rotation parameters, ending between chrons $24 \mathrm{y}$ and $21 \mathrm{y}$, and a later period of slower change with significant statistical overlap in pole locations. This subdivision might be related to changes in driving forces introduced as a consequence of jumps of the Carlsberg Ridge crest that resulted in the end of spreading in the Mascarene Basin (Eagles \& Hoang, 2013; Eagles \& Wibisono, 2013). A final epoch begins with chron 13y, and is characterised by northwards shifts between successive finite rotation poles. It is possible that this is characteristic of the introduction of new driving forces to the regional circuit by rupture of the African plate into Somalian and Nubian subplates.

\subsection{Plate Kinematic Reconstruction Data Sets}

The data used for building the plate kinematic reconstruction maps include magnetic anomaly picks from Eagles and Wibisono (2013) (in the Mascarene Basin), Cande et al. (2010) and Eagles and Hoang (2013) (in the eastern Somali basin), König and Jokat (2010) (in the Mozambique Basin), and Cande et al. (2010) (on the flanks of the SW Indian Ridge). Data in the West Somali Basin were newly interpreted for this study (see section 2.1).

Further magnetic anomaly isochrons have been tentatively identified in the Laxmi Basin according to various schemes (e.g. Bhattacharya et al., 1994; Eagles \& Wibisono, 2013). These identifications vary greatly, and in view of the uncertainty we use no magnetic isochron picks from the Laxmi Basin.

In the Mozambique Basin, Leinweber and Jokat (2012) further interpreted König and Jokat's (2010) magnetic anomaly data to identify a Continent-Ocean-Boundary (COB) that lies much closer to the coast in the Mozambique Channel than estimated by other authors (e.g. Raillard, 1990), and a continuation of the magnetic isochron sequence to much older ages in the Mozambique Basin (chron M41n; $166 \mathrm{Ma}$ ) than the chron M25n (154.37 Ma) identifications made with older data. We do not use these picks explicitly because they are made in very low amplitude anomalies that make the interpretation difficult to justify.

\subsection{Plate Kinematic Reconstruction Workflow}

Plate kinematic reconstruction maps were generated by cropping gridded bathymetric data within isochronous plate boundary polygons, and rotating the cropped data using grdrotater, grdmask and grdmath from the GMT Suite of tools (Wessel et al., 2013). The rotation parameters describing the motions of the plates are taken from Eagles \& Hoang (2013), Eagles \& Wibisono (2013) and from section 2.1., interpolated at 1 million year intervals (Table 1).

The plate boundary polygons (Fig. 4) were generated by digitizing paleo-ridge segments passing through the magnetic anomaly picks described in the previous section and paleo-transform segments whose locations are preserved within fracture zones that are evident in the gravity data. To do this, we used Golden Software's Didger 5 digitizing software and the free-air gravity data from Sandwell et al. (2014). These data image fossil fracture zones and mid-ocean ridges from the Mozambique and West Somali basins in particular more clearly than in previous datasets.

For the very oldest reconstructions, at times before the onset of seafloor spreading, pre-stretching continental limits were estimated from the positive and negative gravity anomaly couplets at the extended continental margin segments in the Riiser-Larsen Sea and Mozambique Basin. These estimates (labeled AAM in Figure 2) were used in the same way as the magnetic isochron picks in the rest of the inversion model. Eagles, Pérez-Díaz \& Scarselli (2015) show that the locational uncertainty

This article is protected by copyright. All rights reserved. 
of features picked in this way is similar to the numerical uncertainty in restoration of continent-ocean boundaries by quantitative palinspastic reconstruction techniques like that of Williams et al. (2011), but the location itself is independent of a starting set of rotations. The choice of such a short length of conjugate margins means there is little risk of propagating errors from unrecognized diachronous breakup into the model's earliest stage.

\section{High-resolution kinematic reconstruction of the Africa-India-Antarctica plate circuit}

We present the new plate kinematic model as four different phases which show distinctive periods of evolution of the Indian Ocean, separated by major tectonic changes such as ridge jumps or the initiation of new spreading ridges and the effect on the tectonic development of the conjugate East African and West Madagascan margins. The four phases are outlined in Table 2.

\subsection{Phase 1 - Starting at 183-177 Ma: Separation of East and West Gondwana}

The first plate tectonic phase is characterised by the separation of East Gondwana, bearing the future continents and microcontinents of Madagascar, the Seychelles, India, East Antarctica, and Australia from West Gondwana, bearing Africa and South America. This led initially to continental rifting and eventually to breakup and the onset of seafloor spreading in the newly created West Somali and Mozambique basins.

Figure 5 (a) shows the plates of the future Africa-Antarctica-India plate system fully reassembled in their relative positions prior to fragmentation of the Gondwana supercontinent at the beginning of Phase 1 (within the time period of 183-177 Ma). The timing of this reconstruction is based on the assumption that the onset of plate divergence would have been accompanied by the eruption of the Karoo volcanics in southeast Africa (Eagles \& König, 2008, Encarnación et al., 1996) and their Ferrar counterparts in Antarctica (White \& McKenzie, 1989). Alternative timings have been based on extrapolation of spreading rates from magnetic isochrons ( 165 Ma; Roeser et al., 1996; Leinweber \& Jokat, 2013) and indirect dating of seaward dipping basalt flows in the Mozambique Basin (pre-169 Ma; Mueller and Jokat, 2017). In contrast, igneous rocks from the margins of the West Somali basin have not been used to determine the timing of the onset of plate divergence. These events marked the end of the intracontinental Karoo rifting episodes (Carboniferous to Late Triassic/Early Jurassic) and the beginning of a new, separate rifting phase that would lead to breakup of Gondwana.

The following conjugate margin segments have been identified from this initial reconstruction; (1) conjugate East African and Indian Margins (EA-IND), (2) conjugate East African and West Madagascan margins (EA-MAD), (3) the corresponding margin of West Madagascar (MAD-EA) and (4) conjugate East African and Antarctica margins (EA-ANT) (Fig. 5 (a)).

There is significant overlap between the Seychelles microcontinent and the northern part of India with Somalia (Fig. 5 (a)). Hammond et al. (2013) documented that the Seychelles are underlain by continental crust, meaning that the overlap is an observation of significance for the plate kinematic model or its interpretation. If the model rotations are accepted as reliable, then the overlap might be interpreted as a consequence of extension of the continental margins, or as a consequence of diachronous rifting that was accommodated by short-lived intracontinental plate boundaries, as suggested for the Muglad-Anza rift (which stretches from southern Sudan, through South Sudan and Kenya) by Pérez-Díaz and Eagles (2014).

An obvious feature worth noting in the FIT 183-177 Ma image (Fig. 5 (a)) is the overlap between East Antarctica and the Mozambique coastal plain (MCP). The overlap persists in the reconstructions for 175 (Fig. 5 (b)) and $165 \mathrm{Ma}$ (Fig. 5 (c)), and is a feature of numerous alternative reconstructions (e.g. Eagles and König, 2008; Leinweber \& Jokat, 2012; Davis et al., 2016). Many of these authors have suggested that the overlap signifies the Mozambique coastal plain to be underlain by magmatic crust that did not yet exist at FIT times. Consistent with this, backstripping of the plain's thick sedimentary

This article is protected by copyright. All rights reserved. 
sequence suggests the underlying lithosphere subsided at rates reminiscent of oceanic lithosphere (Watts, 2001). However, recent seismological investigations suggest a crustal thickness of about 20 $\mathrm{km}$, which would be unusually thick for oceanic crust (Domingues et al., 2016; Fonseca et al., 2014). Deep seismic data would help to confirm whether the Mozambique side of the overlap is underlain by stretched, transitional or oceanic crust with a thick volcanic cover.

With our rotations, the conjugate margins of East Africa and Madagascar reconstruct to relative positions similar to those modelled by Smith and Hallam (1970), Coffin and Rabinowitz (1987), Eagles and König (2008) and Klimke and Franke (2016). Much tighter fitting reconstructions are presented by Reeves (2014), Davis et al. (2016) and Phethean et al. (2016), all of which aim to closely match the shelf outlines at times before seafloor spreading constraints become available. Outboard of the shelves, however, controversy has recently developed regarding the presence of extended continental or of oceanic crust around the Davie Fracture Zone (Danforth et al, 2012; Turner et al, 2016; Klimke and Franke, 2016; Phethean et al., 2016; Klimke et al., 2016). This controversy implies reconstruction overlaps as great as $270 \mathrm{~km}$ for the tighter-fit models, implausibly large to be explained by continental extension. Clearly here, as in many other settings worldwide, the difficulty of accurately and reliably locating the continent-ocean boundary strongly limits its role in the reconstruction process.

During the rift phase (Fig. 5 (b)), plate kinematic and local plate motion vectors demonstrate extension and transtension along a $1000 \mathrm{~km}$ long NNE-SSW trending future plate boundary zone between East Africa (as part of West Gondwana) and India, Madagascar and Antarctica (as parts of the East Gondwana plate). The earlier Karoo rifts followed the regional tectonic trends and inherent structures of the Precambrian basement (Catuneau et al., 2005). However, during the later main rift stage, the regional trends of the future margin segments may not have followed the same orientations. For example, in Madagascar the rift axis migrated west (Clark, 1997; Geiger et al., 2004) and in East Africa the main rift basins were superimposed discordantly over the Karoo basins (Key et al., 2008).

The age assigned to breakup and the onset of seafloor spreading in the Mozambique Basin and Riiser Larsen Sea can be estimated based on extrapolation of magnetic isochron ages towards the continent ocean boundaries. Linear extrapolation of our model's oldest dated stage (M25n-M22n) would suggest an age of $167 \mathrm{Ma}$, comparable to Leinweber and Jokat's (2012) tentative identification of anomaly M41n (165.6 Ma) near the base of the continental slope where they also placed the continent-ocean boundary. Slower early plate divergence rates would imply earlier breakup.

The end of the main rift phase and breakup was followed by the onset of seafloor spreading in the West Somali and Mozambique Basins between East and West Gondwana (Fig. 5 (c)). Motion on the spreading ridges in the two basins was accommodated by dextral strike-slip on the Davie transform fault between parts of Tanzania, Mozambique and Madagascar. For the remainder of phase one, from the onset of seafloor spreading until the abandonment of the plate boundary in the West Somali Basin, the tectonic model describes a stable two plate system as exhibited by the relatively stationary finite rotation poles for this time period (155-133 Ma) (see section 2.1, and figure 2).

\subsection{Phase 2 - Starting at 133 Ma: Separation of Antarctica}

The second phase of tectonic activity in the Indian Ocean involved the cessation of seafloor spreading in the West Somali Basin and its eventual onset in the West Enderby Basin between Madagascar and East Antarctica (Fig. 6 (a)). The timing of this change is still debated. Our model dates the boundary reorganisation to sometime within chron M10n ( 133.9 - 133.5 Ma) as an explicit consequence of the assumption that the model should describe relative motions of just two large plates, East and West Gondwana. After this time, our model's finite rotation poles adopt a south-southwesterly migration path whose consistency and longevity seem difficult to explain as a mere consequence of the removal of model constraints from the West Somali Basin. As noted previously, alternative interpretations of the magnetic anomalies in the West Somali Basin place the end of spreading to just after M0 (126.30$125.93 \mathrm{Ma}$ ), which require motion of a third plate, remain popular and can be defended using magnetic wiggle profiles from the West Somali Basin (e.g. Gibbons et al., 2013; Davis et al., 2016).

This article is protected by copyright. All rights reserved. 
Both timings can be seen as consistent with magnetic isochron patterns in the western Enderby Basin, which seems not to have seen seafloor spreading until around 8 Myr later than the end of spreading in the West Somali Basin (Jokat at al., 2010). In one scenario, the $8 \mathrm{Myr}$-long gap might be filled by continental extension prior to renewed seafloor spreading south of Madagascar; Figure 6a suggests the Mannar and Cauvery basins as locations for this extension. In the other scenario, the switch from seafloor spreading north of Madagascar to south of it could have been achieved more-or-less instantaneously. In the face of all this, and until a self-consistent scheme of isochron interpretations is set up on the basis of new and more coherent magnetic anomaly data, we continue to favour the minimum-complexity (i.e. fewest plates) view of the regional development in early Cretaceous times.

The new ENE-WSW trending spreading centre between EA-IND-MAD and EA-ANT strongly altered the orientation of the plate motion vectors and kinematics within the EA-IND-MAD plate assembly (Fig. 6 (a)). NW-SE oriented local plate motion vectors trending oblique to the N-S trending margins of the southern EA-MAD and MAD-EA indicate the potential for strike-slip or transpressional deformation along these margin segments. Accordingly, a major unconformity marks the onset of start of this phase (end Hauterivian/Barremian) along the margin segments bordering the Somali Basin i.e. the EA-IND segment (Bosellini, 1992) and the northern MAD-EA segment (Coffin \& Rabinowitz, 1988). Key et al. (2008) suggest that early phase 2 deposition was controlled by renewed rifting and extensive inland erosion in the Rovuma Basin (southern EA-MAD) whilst in the Angoche Basin (southern EA-MAD/EA-ANT) a short-lived period of tectonic uplift followed the end of movement on the Davie Facture Zone (Mahanjane 2014).

\subsection{Phase 3 - Starting at 89 Ma: Separation of India and Madagascar}

The third phase saw the continuation of Antarctica-African seafloor spreading along the SWIR, but is characterized by a dramatic change in tectonic activity in the Indian Ocean. This change was associated with the initiation of a new spreading ridge and the opening of the Mascarene Basin, separating India and Madagascar (Fig. 7). The timing of activity in the Mascarene Basin is constrained mostly by the magnetic isochron interpretations described in section 2 , but its earliest dated products are the $\sim 89$ Ma Morondava volcanics (Storey et al 1997) in Madagascar, whose eruption is attributed to the arrival of the Marion mantle plume (Fig. 7 (a)). Spreading in the Mascarene Basin continued until its abandonment shortly after the young end of chron 27n (61.65 Ma) (Eagles \& Wibisono, 2013).

Along Africa's southeastern plate boundary with Antarctica the spreading direction between the two plates remained in an approximately NW-SE direction along the SWIR (Fig. 7 (b)). However, further north, the regional tectonics at the East African and West Madagascan margins were more likely dominated by spreading along the newly formed N-S trending Mascarene Ridge along the eastern boundary of the African plate.

Local plate motion vectors varied from a NE-SW direction in the northern Somalia margin to an E-W direction in the Mozambique margin. Consequently, in the NE-SW oriented EA-IND, northern EAMAD, northern and central EA-ANT segments, the local plate motion vectors were oriented mostly parallel to the continental margin segments indicating a phase of tectonic quiescence and passive margin development during the late post-rift or drift stage. ENE-WSW to E-W local plate motion vectors trended perpendicular to the N-S trending margin segments of the southern EA-MAD and MAD-EA margins indicating some potential for inversion of earlier strike-slip structures in this stage. Corresponding to the opening of the Mascarene Basin, Clark (1998) describes renewed tectonic activity in the basins of western Madagascar, with strike-slip faulting and contractional folding occurring in the Late Cretaceous. Towards the end of this phase, a number of major tectonic changes and boundary relocations occurred in the oceanic crust between India and Madagascar.

This article is protected by copyright. All rights reserved. 


\subsubsection{Opening of the Laxmi Basin and the Speed of the Indian Plate}

The next important boundary relocation occurred during chron 30n (66.398 - 68.196 Ma). Eagles \& Wibisono (2013) concluded that evidence for oceanic accretion between chrons 30n and 28n was lacking from the Seychelles - India corridor in the very northern part of the Mascarene Basin and neighbouring flanks of the Carlsberg Ridge. They tentatively identified the missing crust to be present in the Laxmi Basin (Fig. 7 (c)), where magnetic anomaly profiles are short and had been previously interpreted in terms of much older seafloor spreading.

To further constrain the age of the Laxmi Basin, alternative reconstructions were attempted for $\mathrm{C} 32 \mathrm{n} .1 \mathrm{n}$ and $\mathrm{C} 34 \mathrm{n}$ using three alternative assumed ages for the initiation of plate divergence in the Laxmi Basin: C29o (65.12 Ma), $66 \mathrm{Ma}$ and $67 \mathrm{Ma}$. It was found that $67 \mathrm{Ma}$ minimized overlap of the Seychelles microcontinent with the Indian-Madagascan and Somali continental margins. Therefore, the Laxmi Basin is modelled here as active between $67 \mathrm{Ma}$ (chron 30) and $64 \mathrm{Ma}$ (during Chron 28n).

The Indian Plate had been accelerating northwards throughout the opening of the Mascarene Basin. This acceleration has been related to the influence of the Marion plume at the southern edge of the plate (van Hinsbergen et al., 2011) or to the action of double subduction at its northern edge (Jagoutz et al., 2015). During chron 30n (66.398 - 68.196 Ma), a further short-lived acceleration saw the speed of the Indian plate increased by $150-200 \%$, until it was moving faster than might be thought possible purely in response to the pull of a freely descending slab at its northern edge. Eagles \& Wibisono (2013) suggested that relocation of part of the boundary between India and Madagascar from the Mascarene to the Laxmi Basin to the region above the Deccan-Réunion mantle plume led to the development of an unusually high mid-ocean ridge, from which an increased ridge push force contributed to the short period of unusually fast plate motion. They suggested that these conditions lasted for only a short while until the plate boundary in the Laxmi Basin was abandoned as the Carlsberg Ridge propagated rapidly into the region to the west of the basin. The occurrence of a similar short-lived acceleration in the new model for African-East Antarctic divergence (Figure 2c) is difficult to explain in similar terms, because of the great area of the African plate and the location of its boundary with the East Antarctic plate, opposing the direction of the proposed increase in Laxmi Basin ridge push for the African plate. A more prosaic interpretation of this event might be in terms of a timescale error affecting the dates assigned to chron 30 .

\subsubsection{Rotation of Seychelles microplate and Origin of the Amirante Trench}

Isolation and independent movement of a small Seychelles plate (Fig. 7 (c)), was long suspected as an explanation for the islands' continental crustal composition and its intra-oceanic location. For a long time, though, the timing and details of the plate were poorly understood. Up until chron 29n $(65.12-$ $64.13 \mathrm{Ma}$ ) the Seychelles had been a part of the Indian plate, until the islands moved and rotated independently before becoming attached to the African plate. It is likely that the arcuate Amirante Trench to the southwest of the Seychelles platform acquired its present-day morphology during this rotation (Fig. 7 (c)), and, for a short time, formed part of the boundary between the Seychelles plate and the African plate. The present-day morphology of the trench, a deep, steep-sided, markedly arcuate trough with a rough but not tilted basement, suggests its extinction occurred whilst it was accommodating plate divergence at slow or ultraslow seafloor spreading rates (Eagles \& Hoang, 2013), but that earlier in its development it accommodated transverse and convergent deformation as well. Our kinematic model and the rotation parameters from Eagles \& Hoang (2013) suggest that this is a result of the trench forming part of a low-strain-rate 'diffuse' plate boundary zone between Africa and the Seychelles. The early stages of this motion involve more widespread plate convergence and so are less confidently constrained than the later stages. As a consequence, as we noted above, it is difficult to conclude whether or not the 'FIT' aged overlap between the Seychelles and the Somali margin is a result of model deficiency or should be interpreted in terms of plate boundary propagation and/or continental extension.

This article is protected by copyright. All rights reserved. 
Isolation of the Seychelles microplate occurred as the result of a combination of ridge propagation and ridge jumping. The Mascarene Ridge became extinct at $\sim 61 \mathrm{Ma}$. We date spreading in the Laxmi Basin at approximately $67 \mathrm{Ma}$ until abandonment during chron 28n (64.667 - 63.494 Ma) following the jump to the Carlsberg ridge. As a result, there was a period of about 6 million years during which ridges were active on either side of the Seychelles plateau, leading to the isolation of a small plate between them (Fig. 7 (c)). The Seychelles plate ceased independent motion and rotation during chron $26 n$ (59.237 - 58.959 Ma) when it became attached to the African plate.

\subsubsection{Origin and position of the Mascarene Plateau}

The origin of the crust beneath the Mascarene Plateau is unclear. Duncan \& Hargreaves (1990) wrote that it is comprised of Cenozoic basalts, which were emplaced during the passage of the DeccanRéunion plume close the basin margin. However, more recently, Torsvik et al. (2013) and Ashwal et al. (2017) used U-Pb dating to ascertain the ages of zircon xenocrysts separated from beach sands derived directly from young volcanic rocks on Mauritius, at the southern end of the Mascarene Plateau. They found numerous zircons with Palaeoproterozoic (>1,971 Ma) and Neoproterozoic (between 660 and $840 \mathrm{Ma}$ ) ages, and concluded that they were assimilated from ancient fragments of continental lithosphere beneath Mauritius and brought to the surface by plume related melts. Furthermore, crustal thickness maps from inversion of gravity data show a connecting block of anomalously thick crust that lies underneath Mauritius and the Mascarene Plateau, and extends northwards in an arc towards the Seychelles (Torsvik et al. 2013). The same authors suggest a Precambrian microcontinent, which they named Mauritia, for the origin of these xenocrysts and the reason for the anomalously thick crust, isolated by ridge jumps and covered in Cenozoic plume related lavas. They built a plate kinematic model that leaves a large space between India and Madagascar, almost as wide as Madagascar itself, for Mauritia. Most other reconstructions of the Indian and Madagascan conjugate margins leave much less space for such a microcontinent (e.g. Gibbons et al., 2013; Davis et al., 2016). Ratheesh-Kumar et al., (2014) found Mauritia to be unnecessary in their modelling supporting a fit between Madagascar and India based on flexural isostasy, elastic thickness, Moho depth data and matching tectonic lineaments, lithologies and geochronological belts.

Whilst accepting the significance of the zircon ages, our model shows a close fit between India and Madagascar, without the need for any significantly large intervening microcontinent blocks (Fig. 7 (a)). As a result, we consider most of the anomalous crustal thickness of the Mascarene Plateau to be a consequence of magmatic thickening during its journey over the Deccan-Réunion plume, and the area of any continental component to be too small to depict usefully in our reconstructions.

\subsection{Phase 4 - Starting at 60 Ma: Separation of India and the Mascarene Plateau}

The fourth tectonic phase involves the separation of India and the Mascarene Plateau, accommodated by spreading on the Carlsberg and Central Indian Ridges (CIR), which are still active today (Fig. 8). Spreading on the Carlsberg ridge started at the young end of chron C28n (63.10 Ma) and propagated southwards, separating India and the Mascarene Plateau between chrons C27n and C26n (61.65 and $58.38 \mathrm{Ma})$.

The rest of this phase is defined not by any significant tectonic changes within the NW Indian Ocean itself, but by changes occurring at the other margins of its plates. These include the development of the East African Rift System and the collisions of India and Africa with Eurasia. The latter changes led to considerable complexity in the relative movement of Africa and Antarctica in the period from $\sim 58$ to $53 \mathrm{Ma}$. During this time, the relative motion changes from approximately NNE-SSW to NWSE before reverting back to NNE-SSW again. This has given rise to pronounced curves in the fracture zones on the flanks of the SWIR (Fig. 8 (b)).

This article is protected by copyright. All rights reserved. 
Finite rotations in our model of Antarctic-Africa relative motion migrate southwards in the period after chrons $30 \mathrm{y}-28 \mathrm{o}(66.398 \mathrm{Ma}-63.494 \mathrm{Ma})$, at first rapidly until chrons $26 \mathrm{y}$ to $24 \mathrm{y}(58.959 \mathrm{Ma}-$ $52.62 \mathrm{Ma}$ ), and afterwards more slowly until chron 13y (33.147 Ma) (see Section 2.1, Fig. 2). The initial slowdown has been interpreted in terms of the influence of the Deccan plume near the AfricanIndia plate boundary (Cande \& Stegman, 2011), and its later stages in terms of the eventual continental collision between Africa and Europe (Nankivell, 1997). After chron 13, the progression of finite rotation poles adopts a northwards orientation. This abrupt change suggests a new tectonic influence beginning at $13 \mathrm{y}(33.147 \mathrm{Ma})$, which could be related to the onset of continental rifting linked to a new plate boundary in the East African Rift System (e.g. Roberts et al., 2012).

At the beginning of this phase, three active spreading ridges existed; the Carlsberg Ridge (CR), the Central Indian Ridge (CIR) and the Southwest Indian Ridge (SWIR).

At this stage the local plate motion vectors along the East African and West Madagascan margins were orientated in a NE-SW direction as a consequence of active spreading on the Carlsberg and Central Indian Ridges. Accordingly, in the NE-SW oriented EA-IND, northern EA-MAD, northern and central EA-ANT segments, the local plate motion vectors were still oriented mostly parallel to the continental margin segments (Fig. 8 (b)) indicating tectonic quiescence and passive margin conditions. The start of this phase correlates well with the formation of the gravity-driven Lamu deepwater fold-and-thrust belt offshore Kenya (Cruciani \& Barchi, 2016). The N-S trending margin segments of the southern EA-MAD and MAD-EA margins were characterised by more oblique trending local plate motion vectors indicating potential transpressional or strike-slip deformation in this phase (Fig. 9 (b)). Further south, the direction of plate divergence rapidly flip-flopped from $\mathrm{N}$ to NW between 58 to 53 Ma then back to N. Figure 2 (c) shows the spreading azimuth deviating from north by almost $60^{\circ}$, corresponding to a drop in the spreading rate.

Later in phase 4, the development of the East African margin is likely to have been strongly influenced by the neighbouring East African Rift System (EARS). This may be reflected in the progression of finite rotation poles discussed earlier in this section. However, it seems the effects were largely local. Examples include: (i) Uplift and doming prior to the onset of rifting as suggested by Wichura et al. (2011) for the Kenya dome in the Mid-Miocene, and linked to the Oligocene by MacGregor (2015); (ii) Uplift and increased sediment input triggered by the EARS may have led to loading and collapse of prograding sediment wedges, for example the Rovuma deep-water-fold-andthrust-belt (Mahanjane \& Franke, 2014)).

\section{Discussion}

The detailed plate tectonic model and derived plate tectonic evolutionary stages of the Northwest Indian Ocean form the basis of a chronostratigraphic chart correlating the fundamental regional tectonic events and megasequence types of the conjugate margin segments of East Africa with India, Madagascar and Antarctica (Fig. 9).

This margin-scale chronostratigraphic correlation will in turn form the basis for a more detailed future margin-scale tectono-stratigraphic framework integrating geological and geophysical data from sedimentary basins to better understand their formation and evolution along the East African and West Madagascan rifted continental margins. Here, however, we discuss possible correlations at plate margin scale.

The four main tectonic phases identified in our plate kinematic model, and the preceding Karoo phase, are shown by coloured background panels of the chart in Figure 9. For the margin-scale correlation in this paper, the chronostratigraphic chart utilises a simplified tectono-stratigraphy of the sedimentary basins on the various East Africa and West Madagascar margin segments, compiled from literature. This tectonostratigraphy comprises the following dominant megasequences: the Karoo syn-rift, Main syn-rift, transitional, early post-rift, late post-rift and modern margin. This tectono-stratigraphic classification is applied to the margin segments based on lithological and structural features and the stratigraphic boundaries described in literature and subsequently placed into the context of our plate

This article is protected by copyright. All rights reserved. 
kinematic model. The tectonic regimes of each margin segment derived from the plate kinematic model and orientation of local plate motion vectors (Chapter 3 ) are shown as coloured bars along the left of each margin segment and the average plate motion vectors relative to conjugate margin segments are shown by the black arrows.

The following section briefly summarises the key tectono-stratigraphic events in the conjugate margin segments of East Africa with India, Madagascar and Antarctica and their correlation within the newly derived margin-scale chronostratigraphic framework.

\subsection{Pre-phase 1: Karoo}

The Karoo Phase refers to the phase of intermittent, intracontinental rifting events that affected the Pangea supercontinent which were ultimately unsuccessful in reaching the final breakup stage. The age of Karoo sediments determined in the margin segments varies considerably, consistent with the idea of their deposition during a rifting phase that potentially stretched all the way from the Late Carboniferous through the Permo-Triassic and into the Early Jurassic, when Pangea had reached its maximum extent (Catuneanu et al., 2005).

Along the future margins of East Africa and West Madagascar, Karoo rifting mainly followed inherited structural basement trends, e.g. the Mozambique Metamorphic Belt causing fairly discrete, linear NE trending rifts (Catuneau et al., 2005). A number of smaller north to northwest trending pullapart basins suggest that the East African/Malagasy Karoo Basins were formed by left-lateral transtension between India/Madagascar and Africa (Catuneau et al., 2005; Wopfner et al., 1993).

The Karoo sediments are predominantly continental in nature and deposited unconformably on top of the metamorphic basement. Sporadic marine incursions from the Tethyan Ocean in the North occurred, and reached as far south as Madagascar (Wopfner, 1991). These rifting events failed to cause the breakup of Gondwana and culminated in the early Jurassic eruption of the Karoo Large Igneous Province within the time period 183-177 Ma (Cox 1992; Jourdan et al. 2005).

Dates for the boundary between the Karoo and Main Syn-rift megasequence vary greatly along the margins. Along the East African margin segment conjugate to Madagascar the boundary is dated at $\sim 200 \mathrm{Ma}$ (Coffin \& Rabinowitz, 1988; Key et al., 2008). However, on the Madagascan margin it has been identified much later at $\sim 183$ Ma (Papini \& Benvenuti, 2008; Geiger, 2004), accompanying the emplacement of the Karroo-Ferrar Large Igneous Province (Cox 1992; Jourdan et al. 2005) and the onset of Phase 1 of our plate kinematic model (see Fig. 9). Along the EA-IND margin the boundary between Karoo and Main syn-rift has been placed at approx. 190 Ma (Bosellini, 1992). However, in the EA-ANT margin segment the Karoo megasequence extends into Phase 1 (Mahanjane, 2012). Variability of this order might be expected in a set of basins that have been sparsely studied using varying techniques and data sets over a 30 year period. To what extent it might also reflect the progressive break-up of Pangea or asymmetrical rifting styles, remains to be seen on the basis of future more detailed work.

\subsection{Phase 1: Latest Karoo / Main Syn-Rift / Transitional / Breakup / Early Post Rift}

As previously described in section 3.2, Phase 1 of our tectonic model includes the rifting of East Gondwana (comprising Madagascar/India/Antarctica/Seychelles) and West Gondwana (comprising Africa/South America), and their eventual breakup and subsequent seafloor spreading in the West Somali and Mozambique Basins (Fig. 5 a-c). Karoo syn-rift, main syn-rift, transitional and early postrift megasequences are all either present or partially present in this phase (Fig. 9).

The main syn-rift megasequence is associated with the distinct, concise stage of rifting that successfully led to the breakup of East and West Gondwana. Characteristically, syn-rift sedimentation is controlled by rift-related extensional faulting, with sediments accumulating within half grabens (Coffin \& Rabonowitz, 1988; Bosellini, 1992; Mbede \& Dualeh, 1997; Clark, 1998; Geiger et al., 2004; Mahanjane, 2012). Sediments were deposited under mostly shallow marine conditions along the

This article is protected by copyright. All rights reserved. 
EA-IND and MAD-EA margin segments (Bosellini, 1992; Geiger, 2004), with a mixture of continental, transitional and shallow water facies along EA-MAD (Coffin \& Rabinowitz, 1988; Mbede \& Dualeh, 1997; Hudson \& Nicholas, 2014), and shelf to marine sediments along EA-ANT (Mahanjane et al., 2014). In some margin segments, the main syn-rift megasequence is easily identifiable (e.g. MAD-EA), however, in others it is difficult to distinguish from the Karoo megasequence (EA-IND, EA-MAD).

Along the conjugate Madagascan margin, the onset of the main syn-rift stage corresponds to the beginning of Phase 1 of our plate kinematic model. However, main syn-rift deposition began earlier in the EA-IND and EA-MAD margin segments and Karoo syn-rift deposition continued well into phase 1 in the EA-ANT margin (see section 4.1 above). By nature, the main syn-rift deposition is very variable because its onset happened in isolated rift basins first. As a consequence of the staggered breakup, the main syn-rift sediments in the EA-ANT segment are younger than the EA-MAD and MAD- EA segments. However, main syn-rift sediments of similar age are found along the EA-IND segments.

A characteristic transitional megasequence has been identified in the EA-ANT segment only, where it consists of mixed marine/continental sediments deposited during an early post-rift sag phase before final breakup occurred (Mahanjane, 2012).

The age of the breakup unconformity, separating the main syn-rift (or transitional) megasequence from the early post-rift megasequence also is diachronous along the margins. The breakup age of the EA-MAD segment has been given at the end of the Jurassic 174 Ma (Coffin \& Rabinowitz, 1988) and for its conjugate MAD-EA segment the breakup age is represented by the Aalenian-Bajocian boundary, approx. $170 \mathrm{Ma}$ (Geiger, 2004). Stratigraphic constraints in Somalia suggest breakup just to the north, along the EA-IND segment, occurred during the Callovian $165 \mathrm{Ma}$ (Bosellini, 1992). The discrepancy and age of these dates could be due to problems in identifying or dating the breakup unconformity, or due to erosion and removal of younger syn-rift sediments at the end of the rifting phase. Magnetic reversal isochrons in the Mozambique Basin suggest that breakup at the EA-ANT margin had occurred by 164-166 Ma (Leinweber and Jokat, 2012; Mueller et al., 2017), whereas stratigraphic evidence suggests a somewhat later date of approximately $157 \mathrm{Ma}$ (Mahanjane, 2012). Both interpretations agree broadly with our plate kinematic model, in which EA-ANT breakup occurs around $160 \mathrm{Ma}$, later than at the other margin segments. Interpretations of the Mozambique coastal plains as underlain by stretched continental crust or transitional crust (e.g. Leinweber et al, 2011) are consistent with the notion of a longer-lasting period of continental stretching before breakup.

The orientations of plate motion vectors during the main syn-rift is described in section 3 (Fig. 5). Extension occurred in a NW-SE direction, perpendicular to most margin segments, facilitating orthogonal rifting. Exceptions to this pattern are the southern EA-MAD and MAD-EA segments characterised by dextral transtension on what was to become the Davie Fracture Zone.

Following breakup, a thick succession of post-rift sediments was deposited along all margin segments. The post-rift succession has been subdivided into three distinct megasequences; early post-rift, late post-rift and modern margin. These subdivisions are marked by significant changes in the stratigraphic succession or tectonic development of the basins such as the sudden change in depositional facies from shallow to deep marine sediments and vice versa, or the occurrence of major regional unconformities that can be suggested to relate to phases of tectonic uplift.

The Early Post-rift megasequence stretches from Phase 1 through Phase 2 and into Phase 3 of our plate kinematic model. Early post-rift sequences are characterised by changes of the depositional environment from shallow-marine to deep marine sediments as a consequence of thermal subsidence of the stretched continental and oceanic crust the margin segments following breakup.

Within Phase 1, the initial stages of early post-rift deposition along the EA margin segments are punctuated by a number of localised unconformities followed by more consistent and sustained deposition at the start of the Cretaceous. The exception to this was observed at the EA-IND segment, where a major pre-Aptian erosional event removed early Cretaceous sediments (Bosellini, 1992).

This article is protected by copyright. All rights reserved. 
For the rest of Phase 1, most of the Early Post-rift megasequence sediments are characterised as an undifferentiated passive margin sequence, indicating relative tectonic quiescence. Local exceptions are the southern EA-MAD and southern MAD-EA margin segments, which remained close to active plate boundary segments of the future Davie Fracture Zone accommodating strike-slip tectonics. Latest Jurassic-to early Cretaceous unconformities in the EA-IND and its neighbouring northern EAMAD margin segments cannot be directly correlated with any of the kinematic model's main events. In contrast, the neighbouring Anza Rift was a site of Berriasian-Barremian sedimentation that accompanied tectonic activity (Bosworth and Morley, 1994), effecting the development of the EAIND and EA-MAD segments.

\subsection{Phase 2: Early Post-rift}

Deposition of the early post-rift megasequence continued throughout Phase 2 (Fig. 9). Phase 2 begins with a boundary reorganisation in the NW Indian Ocean caused by the cessation of seafloor spreading in the West Somali Basin and its onset in or near the West Enderby Basin separating Madagascar and India from East Antarctica (section 3.2, Fig. 6). Following this reconfiguration, unconformities form within 3 million years in the MAD-EA and EA-ANT margin segments (Coffin \& Rabinowitz, 1988; Mahanjane, 2014). Given their timing, these unconformities can be related to the far-field effects of the plate boundary change described in our plate kinematic model. In contrast, all of the unconformities pre-date the alternatively-advocated later (post-M0r; $124.6 \mathrm{Ma}$ ) cessation of seafloor spreading in the West Somali Basin (Gibbons et al., 2013; Davis et al. 2016; sections 2.1 and 3.2).

As described in section 4.2, the boundary relocation caused a change in the orientation of the local plate motion vectors, rotating them to NW-SE. This orientation is perpendicular to the EA-IND, northern EA-MAD, northern MAD-EA and EA-ANT margin segments, which thus were exposed to the potential for regional uplift and inversion tectonics during phase 2 (Fig. 6 (a), 9). Regional unconformities that might be associated with this possibility are rare, potentially reflecting the relatively young age and weak associated ridge push force from the SWIR to the SW of Madagascar.

Those unconformities that have been identified in the EA-ANT and southern EA-MAD segments are limited to an Albian-Cenomanian surface (Salman \& Abdula, 1995; Key et al., 2008) but might alternatively be related to the 'SOLIP' large igneous province formation at the Agulhas Plateau south of South Africa.

\subsection{Phase 3: Early and Late Post-rift}

The beginning of Phase 3 in our plate kinematic model is defined by the initiation of the new Mascarene ridge opening the Mascarene Basin and separating India from Madagascar (Section 3.3, Fig.7).

Early post-rift sedimentation continued into the early stage of Phase 3. Late post-rift deposition began by the end of Phase 3 in the EA-IND, southern EA-MAD and EA-ANT margin segments. However, in the northern EA-MAD and MAD-EA margins segments, late post-rift sedimentation did not start until Phase 4 . The late post-rift stage is dominated by generally slower thermal subsidence and basinward progradation of depositional systems consisting of deep-water sediments e.g. shales, marls, mudstones and turbiditic sandstones (Salman \& Abdula, 1995; Bosellini, 1992; Key et al., 2008).

We expect the initiation of the Mascarene Ridge to have affected the East African and West Madagascan margins. However, there is little evidence for any effects in the tectono-stratigraphy (Fig. 9) besides an unconformity at a roughly corresponding time in the northern EA-MAD segment linked to renewed basement uplift (Nyagah, 1995).

The boundary between the early and late post-rift megasequences is marked by a major regional unconformity ranging from Maastrichtian age (Late Cretaceous) in the EA-IND, southern EA-MAD and EA-ANT margin segments to Paleocene age in the northern EA-MAD and the conjugate northern MAD-EA margin segments. These unconformities overlap in time with important tectonic changes

This article is protected by copyright. All rights reserved. 
throughout the Indian Ocean as identified in our plate kinematic model and described in detail in section 3. These plate tectonic events include the arrival/peak activity of the Deccan-Réunion Plume, the end of seafloor spreading in the Mascarene Basin, the rotation of the Seychelles plate, the opening of the Laxmi Basin and the initiation of seafloor spreading on the Carlsberg Ridge. All these may have had far-field effects on the East African and West Madagascan margins.

The orientation of the local plate motion vectors during phase 3 suggests the potential for inversion tectonics along the southern EA-MAD and conjugate southern MAD-EA margin segments, though the lack of regional unconformities suggests that this potential was not realised on regional basin scale and was limited to the basins of western Madagascar (Clark, 1998; see section 3.3). The local plate motion vector orientation of Phase 3 for the EA-IND, northern EA-MAD, northern MAD-EA and the EA-ANT margin segments is mostly subparallel to the strike of the margin segments consistent with a phase of tectonic quiescence and passive margin development during the late post-rift or drift stage.

\subsection{Phase 4: Late Post-rift and Modern Margin}

The start of Phase 4 is marked by the end of seafloor spreading in the Mascarene Basin and the onset of spreading on the Carlsberg Ridge (CR) and Central Indian Ridge (CIR) separating India and the Mascarene Plateau (see Section 3.4, Fig. 8), which continues throughout Phase 4 to the present day.

Deposition of the late post-rift megasequence continues into the early stage of Phase 4 . Within Phase 4, an unconformable boundary separates the Late Post-rift and the Modern margin megasequences (Fig. 9). The modern margin meqasequence is characterised by large prograding deltas and gravitydriven deformation (Mahanjane \& Franke, 2014; Mahanjane et al., 2014).

The onset of the modern margin megasequence within Phase 4 is again discernible by another major unconformity in all margin segments, the timing of which (Oligocene) suggests a link to doming and uplift of the African plate over the Afar plume, prior to the onset of the East African Rift System (Wichura et al., 2011; MacGregor, 2015; Ebinger \& Sleep, 1998). It is expected that the EARS has increased sediment input to the East African margin segments and triggered collapse of sediment wedges at shelf margins, turbidity currents, and the formation of deep-water fold-and-thrust belts (Mahanjane \& Franke, 2014; Mahanjane et al., 2014).

The plate motion vectors are orientated approximately NE-SW, subparallel to most margin segments indicating tectonic quiescence and ongoing passive margin development. The exception is the southern EA-MAD and southern MAD-EA margin segments where the local plate motion vectors trend oblique to the margin segments creating the potential for strike-slip deformation. However, in the sedimentary basins of the East African margin (e.g. Lamu Basin (Kenya), Rovuma Basin (Tanzania/Mozambique)) it is likely that the EARS controlled the regional tectonics since its onset in the Oligocene.

\section{Conclusions}

We have developed and presented a margin-scale chronostratigraphic framework for the correlation of major tectonic events and megasequences in the conjugate margin segments of East Africa and Madagascar based on the results of a new plate kinematic model and published information of related basin fill sequences.

A new plate kinematic model of the Northwest Indian Ocean from 183 Ma to the present day was built using finite rotation poles generated by visual fitting and iterative joint inversion techniques as applied to magnetic isochron and fracture zone data. The result is a comprehensive model that describes the complex evolution of the area including its multiple plate boundary reorganisations leading to the growth of numerous ocean basins between separating land masses and microplates.

The synthesis of plate kinematic results with published tectonic and stratigraphic results for specific margin segments will enable us in future to analyse the impact of margin-wide tectonic processes on

This article is protected by copyright. All rights reserved. 
sedimentary basin development. In addition, the synthesis will establish whether the plate tectonic changes and phases of plate-reconfiguration during the opening of the Indian Ocean have been recorded in the stratigraphy and structure of individual basin along the margins. This is the prerequisite for a margin-scale tectonostratigraphic framework based on plate kinematic model data.

Four tectonic phases of development are recognised for the area:

Phase 1 - Starting at 183-177 Ma: Separation of East Gondwana (including Madagascar/India/Antarctica/Seychelles) and West Gondwana (including Africa/South America) accommodated by seafloor spreading in the West Somali and Mozambique Basins.

This phase saw the deposition of the main syn-rift, transitional and early post-rift megasequences along the East African and West Madagascan margins.

Rifting occurred in a NW-SE direction with dextral transtension on the Davie Fracture Zone.

After breakup, seafloor spreading in the West Somali and Mozambique Basins and strike-slip deformation along the Davie Fracture Zone.

Phase 2 - Starting at 133 Ma: Cessation of spreading in the West Somali Basin, boundary relocation to the south of Madagascar and the separation of Madagascar/India and East Antarctica.

Deposition of the early post-rift megasequence continued.

Phase 3 - Starting at 89 Ma: Onset of seafloor spreading on the Mascarene Ridge, opening of the Mascarene Basin and separation of India and Madagascar.

Deposition of the early post-rift megasequence continued, followed the late post-rift megasequence at the end to this phase.

Phase 4 - Starting at 60 Ma: Cessation of spreading on the Mascarene Ridge, spreading on the Carlsberg and Central Indian Ridges separating India and the Mascarene Plateau.

Late post-rift deposition continued until a major unconformity marked the change to the deposition of the modern margin megasequence.

Future work will provide a more in-depth analysis and correlation of the stratigraphy and structures of individual sedimentary basins along the margin segments to develop a comprehensive margin-scale tectonostratigraphic framework for the correlation of sedimentary basins and their key petroleum system elements.

\section{Acknowledgements}

The presented research is part of a PhD project of the COMPASS industry consortium (Continental Margin Process Analysis, Structures \& Stratigraphy) at Royal Holloway, University of London. We would like to thank the COMPASS consortium for project funding. We thank Stuart Clark and two anonymous reviewers for their constructive comments that have improved the quality of this paper.

\section{References}

ASHWAL, L.D., WIEDENBECK, M. \& TORSVIK, T.H. (2017) Archaean Zircons in Miocene Oceanic Hotspot Rocks Establish Ancient Continental Crust beneath Mauritius. Nat Commun, 8, 14086.

BHATTACHARYA, G. C., CHAUBEY, A. K., MURTY, G. P. S., SRINIVAS, K., SARMA, K. V. L. N. S., SUBRAHMANYAM, V. \& KRISHNA, K. S. (1994), Evidence for seafloor spreading in the Laxmi Basin, northeastern Arabian Sea, Earth Planet. Sci. Lett., 125(1-4).

BOSELLINI, A. (1992), The continental margins of Somalia: structural evolution and sequence stratigraphy, Geol. Geophys. Cont. margins, 185-205.

This article is protected by copyright. All rights reserved. 
BOSWORTH, W. \& MORLEY, C. K. (1994), Structural and stratigraphic evolution of the Anza rift, Kenya, Tectonophysics, 236(1-4), 93-115.

CANDE, S.C., PATRIAT, P. \& DYMENT, J. (2010) Motion between the Indian, Antarctic and African Plates in the Early Cenozoic. Geophysical Journal International, 183, 127-149.

CANDE, S. C. \& PATRIAT, P. (2015), The anticorrelated velocities of Africa and India in the Late Cretaceous and early Cenozoic, Geophys. J. Int., 200(1), 227-243.

CANDE, S.C. \& STEGMAN, D.R. (2011) Indian and African Plate Motions Driven by the Push Force of the Reunion Plume Head. Nature, 475, 47-52.

CATUNEANU, O., WOPFNER, H., ERIKSSON, P.G., CAIRNCROSS, B., RUBIDGE, B.S., SMITH, R.M.H. \& HANCOX, P.J. (2005) The Karoo Basins of South-Central Africa. Journal of African Earth Sciences, 43, 211-253.

CLARK, D. N. (1998), Review of the exploration potential of Madagascar, Houston Geol. Soc. Bull., 40, 23-29.

COFFIN, M. F., \& RABINOWITZ, P. D. (1987), Reconstruction of Madagascar and Africa: Evidence from the Davie fracture zone and western Somali Basin, J. Geophys. Res., 92, 9385-9406, doi:10.1029/JB092iB09p09385.

COFFIN, M. F. \& RABINOWITZ. P. D. (1988), Evolution of the conjugate East AfricanMadagascan margins and the western Somali Basin, Geol. Soc. Am. Spec. Pap., 226,1-79.

COX, K. G. (1992), Karoo igneous activity, and the early stages of the break-up of Gondwanaland, Geol. Soc. London, Spec. Publ., 68(1), 137-148.

CRUCIANI, F. \& BARCHI, M. R. (2016), The Lamu Basin deepwater fold-and-thrust belt: An example of a margin-scale, gravity-driven trust belt along the continental passive margin of East Africa, Tectonics, 35(3), 491-510.

DANFORTH, A., GRANATH, J., HORN, B. \& KOMBA, K. (2012) Hydrocarbon potential of the deep offshore Tanzania Basin in Context of East Africa's Transform Margin, East Africa: Petroleum Province of the $21^{\text {st }}$ century, abstr. Vol., 32-33.

DAVIS, J.K., LAWVER, L.A., NORTON, I.O. \& GAHAGAN, L.M. (2016) New Somali Basin Magnetic Anomalies and a Plate Model for the Early Indian Ocean. Gondwana Research, 34, 16-28.

DEMETS, C., GORDON, R.G. \& ROYER, J.-Y. (2005) Motion between the Indian, Capricorn and Somalian Plates since 20 Ma: Implications for the Timing and Magnitude of Distributed Lithospheric Deformation in the Equatorial Indian Ocean. Geophysical Journal International, 161, 445-468.

DOMINGUES, A., SILVEIRA, G., FERREIRA, A.M.G., CHANG, S.-J., CUSTÓDIO, S. \& FONSECA, J.F.B.D., (2016), Ambient noise tomography of the East African Rift in Mozambique. Geophys. J. Int. 204, 1565-1578.

DUNCAN, R. A, \& R. B. HARGRAVES, R. B. (1990), ${ }^{40} \mathrm{Ar} /{ }^{39} \mathrm{Ar}$ geochronology of basement rocks from the Mascarene Plateau, the Chagos Bank, and the Maldives Ridge, In: Proceedings of the ODP, Sci. Results, 115, 43-51, eds Duncan, R.A. et al., College Station, TX (Ocean Drilling Program)

EAGLES, G. (2004) Tectonic Evolution of the Antarctic-Phoenix Plate System since 15 Ma. Earth and Planetary Science Letters, 217, 97-109.

EAGLES, G. \& KÖNIG, M. (2008) A Model of Plate Kinematics in Gondwana Breakup. Geophysical Journal International, 173, 703-717.

This article is protected by copyright. All rights reserved. 
EAGLES, G. \& HOANG, H.H. (2013) Cretaceous to Present Kinematics of the Indian, African and Seychelles Plates. Geophysical Journal International, 196, 1-14.

EAGLES, G. \& WIBISONO, A.D. (2013) Ridge Push, Mantle Plumes and the Speed of the Indian Plate. Geophysical Journal International, 194, 670-677.

EAGLES, G., PÉREZ-DÍAZ, L. \& SCARSELLI, N. (2015) Getting over Continent Ocean Boundaries. Earth-Science Reviews, 151, 244-265.

EBINGER, C. J. \& SLEEP, N. H. (1998), Cenozoic magmatism throughout east Africa resulting from impact of a single plume, Nature, 395, 788-791.

ENCARNACIÓN, J., FlEMING, T. H., ELliOT, D. H. \& EALES, H. V. (1996), Synchronous emplacement of Ferrar and Karoo dolerites and the early breakup of Gondwana, Geology, 24(6), 535.

FONSECA, J.F.B.D., CHAMUSSA, J., DOMINGUES, A.L., HELFFRICH, G., ANTUNES, E., VAN ASWEGEN, G., PINTO, L. V., CUSTÓDIO, S. \& MANHICA, V.J. (2014), MOZART: A Seismological Investigation of the East African Rift in Central Mozambique. Seismol. Res. Lett. 85, 108-116.

FONTAINE, F. R., BARRUOL, G., TKALĚIÉ, H., WÖLBERN, I., RÜMPKER, G., BODIN, T. \& HAUGMARD, M. (2015), Crustal and uppermost mantle structure variation beneath La Réunion hotspot track, Geophys. J. Int., 203, 107-126.

FORSYTH, D. \& UYEDA, S. (1975), On the Relative Importance of the Driving Forces of Plate Motion, Geophys. J. R. astr. Soc., 43, 163-200.

GAINA, C., TORSVIK, T.H., VAN HINSBERGEN, D.J.J., MEDVEDEV, S., WERNER, S.C. \& LABAILS, C. (2013) The African Plate: A History of Oceanic Crust Accretion and Subduction since the Jurassic. Tectonophysics, 604, 4-25.

GEIGER, M., CLARK, D. N. \& METTE, W. (2004), Reappraisal of the timing of the breakup of Gondwana based on sedimentological and seismic evidence from the Morondava Basin, Madagascar, J. African Earth Sci., 38(4), 363-381.

GIBBONS, A.D., WHITTAKER, J.M. \& MÜLLER, R.D. (2013) The Breakup of East Gondwana: Assimilating Constraints from Cretaceous Ocean Basins around India into a Best-Fit Tectonic Model. Journal of Geophysical Research: Solid Earth, 118(3), 808-822.

HAMMOND, J. O. S., KENDALL, J-M., COLLIER, J. S. \& G. RÜMPKER, G. (2013), The extent of continental crust beneath the Seychelles, Earth Planet. Sci. Lett., 381, 166-176.

HELLINGER, S. J. (1981), The Uncertainties of Finite Rotations in Plate Tectonics, J. Geophys. Res., 86(B10), 9312-9318.

HORNER-JOHNSON, B. C., GORDON, R. G. \& ARGUS, D. F. (2007), Plate kinematic evidence for the existence of a distinct plate between the Nubian and Somalian plates along the Southwest Indian Ridge, J. Geophys. Res., 112(B5).

HUDSON, W. E. \& NICHOLAS, C. J. (2014), The Pindiro Group (Triassic to Early Jurassic Mandawa Basin, southern coastal Tanzania): Definition, palaeoenvironment, and stratigraphy, J. African Earth Sci., 92, 55-67.

JAGOUTZ, O., ROYDEN, L., HOLT, A. F. \& BECKER, T.W. (2015), Anomalously fast convergence of India and Eurasia caused by double subduction, Nat. Geosci., 8(6), 475-478.

JOKAT, W., NOGI, Y. \& LEINWEBER, V. (2010), New aeromagnetic data from the western Enderby Basin and consequences for Antarctic-India break-up, Geophys. Res. Lett., 37(21).

JOURDAN, F., FÉRAUD, G., BERTRAND, H., KAMPUNZU, A. B., TSHOSO, G., WATKEYS, M. K. \& LE GALL, B. (2005), Karoo large igneous province: Brevity, origin, and relation to mass extinction questioned by new 40Ar/39Ar age data, Geology, 33(9), 745.

This article is protected by copyright. All rights reserved. 
KEY, R. M., SMITH, R. A., SMELROR, M., SAETHER, O. M., THORSNES, T., POWELL, J. H., NJANGE, F. \& ZANDAMELA, E. B. (2008), Revised lithostratigraphy of the MesozoicCenozoic succession of the onshore Rovuma Basin, northern coastal Mozambique, South African J. Geol., 111(1), 89-108.

KLIMKE, J., \& FRANKE, D. (2016). Gondwana breakup: no evidence for a Davie Fracture Zone offshore northern Mozambique, Tanzania and Kenya. Terra Nova, 28, 233-244.

KLIMKE, J., FRANKE, D., GAEDICKE, C.,SCHRECKENBERGER, B., SCHNABEL, M., STOLLHOFEN, H., ROSE; J., \& CHAHEIRE, M. (2016). How to identify oceanic crustEvidence for a complex break-up in the Mozambique Channel, off East Africa. Tectonophysics, 693, 436-452.KÖNIG, M. \& JOKAT. W. (2010), Advanced insights into magmatism and volcanism of the Mozambique Ridge and Mozambique Basin in the view of new potential field data, Geophys. J. Int., 180(1), 158-180.

LEINWEBER, V. T. \& JOKAT, W. (2011), Is there continental crust underneath the northern Natal Valley and the Mozambique Coastal Plains?, Geophys. Res. Lett., 38(14).

LEINWEBER, V. T. \& JOKAT, W. (2012), The Jurassic history of the Africa-Antarctica corridor new constraints from magnetic data on the conjugate continental margins, Tectonophysics, 530-531, 87-101.

LISTER, C. (1975), Gravitational drive on oceanic plates caused by thermal contraction, Nature, 257, 663-665.

LIVERMORE, R., NANKIVELL, A., EAGLES, G. \& MORRIS, P. (2005), Paleogene opening of Drake Passage, Earth Planet. Sci. Lett., 236(1-2), 459-470.

MACGREGOR, D. (2015), History of the development of the East African Rift System: A series of interpreted maps through time, J. African Earth Sci., 101, 232-252.

MAHANJANE, E. S. (2012), A geotectonic history of the northern Mozambique Basin including the Beira High - A contribution for the understanding of its development, Mar. Pet. Geol., 36(1), $1-12$.

MAHANJANE, E. S. (2014), The Davie Fracture Zone and adjacent basins in the offshore Mozambique Margin - A new insights for the hydrocarbon potential, Mar. Pet. Geol., 57, 561-571.

MAHANJANE, E. S. \& FRANKE, D. (2014), The Rovuma Delta deep-water fold-and-thrust belt, offshore Mozambique, Tectonophysics, 614, 91-99.

MAHANJANE, E. S., FRANKE, D., LUTZ, R., WINSEMANN, J., EHRHARDT, A., BERGLAR, K. \& REICHERT, C. (2014), Maturity and petroleum systems modelling in the offshore Zambezi delta depression and Angoche basin, northern Mozambique, J. Pet. Geol., 37(4), 329-348.

MBEDE, E. I. \& DUALEH, A. (1997), Chapter 10: The coastal basins of Somalia, Kenya and Tanzania, in Sedimentary Basins of the World, 3, 211-233.

MCKENZIE, D. \& SCLATER, J. G. (1971), The ecolution of the Indian Ocean since the Late Cretaceous, R. Astron.Soc.,Geophys.J., 24(5), 437-528.

MOLNAR, P., PARDO-CASAS, F. \& STOCK, J. (1988), The Cenozoic and Late Cretaceous evolution of the Indian Ocean: uncertainties in the reconstructed positions of the Indian, African and Antarctic plates, Basin Res., 1, 23-40.

MUELLER, C. O., \& JOKAT, W. (2017). Geophysical evidence for the crustal variation and distribution of magmatism along the central coast of Mozambique. Tectonophysics, 712-713, 684-703.

NANKIVELL, A. P. (1997), Tectonic Evolution of the Southern Ocean between Antarctica, South America and Africa over the last $84 \mathrm{Ma}, \mathrm{PhD}$ thesis, Oxford Univ., Oxford, U. K.

This article is protected by copyright. All rights reserved. 
NORTON, I. O. I. \& J. G. SCLATER, J. G. (1979), A model for the evolution of the Indian Ocean and the breakup of Gondwanaland, 84(9), 6803-6830.

NYAGAH, K. (1995), Stratigraphy, depositional history and environments of deposition of Cretaceous through Tertiary strata in the Lamu Basin, southeast Kenya and implications for reservoirs for hydrocarbon exploration, Sediment. Geol., 96(1-2), 43-71.

PATRIAT, P. \& J. SEGOUFIN. J (1988), Reconstruction of the Central Indian Ocean, Tectonics, 155, 211-234.

PÉREZ-DÍAZ, L. \& EAGLES, G. (2014), Constraining South Atlantic growth with seafloor spreading data, Tectonics, 33(9), 1848-1873.

PHETHEAN, J.J.J., KALNINS, L. M., VAN HUNEN, J., BIFFI, P. G., DAVIES, R. J. \& MCCAFFREY, K. J. W. (2016), Madagascar's escape from Africa: A high-resolution plate reconstruction for the Western Somali Basin and implications for supercontinent dispersal, Geochem. Geophys. Geosyst., 17, 5036-5055.

RATHEESH-KUMAR, R. T., ISHWAR-KUMAR, C., WINDLEY, B. F., RAZAKAMANANA, T., NAIR, R. R. \& SAJEEV, K. (2014), India-Madagascar paleo-fit based on flexural isostasy of their rifted margins, Gondwana Res., 28(2), 581-600.

RILEY, T. R., CURTIS, M. L., LEAT, P.T., WATKEYS, M. K., DUNCAN, R. A., MILLAR I. L. \& OWENS, W. H. (2006), Overlap of Karoo and Ferrar Magma Types in KwaZulu-Natal, South Africa, J. Petrol., 47(3), 541-566.

ROBERTS, E. M., STEVENS, N. J., O'CONNOR, P. M., DIRKS, P. H. G. M., GOTTFRIED, M. D., CLYDE, W. C., ARMSTRONG, R. A., KEMP, A. I. S. \& HEMMING, S. (2012), Initiation of the western branch of the East African Rift coeval with the eastern branch, Nat. Geosci., 5(4), 289-294.

ROESER, H.A., FRITSCH, J., \& HINZ, K. (1996). The development of the crust off Dronning Maud Land, east Antarctica. Geological Society, London, Special Publications, 108(1), 243-264.

ROYER, J-Y. \& GORDON, R. G. (1997), The Motion and Boundary Between the Capricorn and Australian Plates, Science, 277(5330), 1268-1274.

ROYER, J.-Y., CHAUBEY, A. K., DYMENT, J., BHATTACHARYA, G. C., SRINIVAS, K., YATHEESH, V. \& RAMPRASAD, T. (2002), Paleogene plate tectonic evolution of the Arabian and Eastern Somali basins, Geol. Soc. London, Spec. Publ., 195(1), 7-23.

SALMAN, G. \& I. ABDULA, I. (1995), Development of the Mozambique and Ruvuma sedimentary basins, offshore Mozambique, Sediment. Geol., 96(1-2), 7-41.

SANDWELL, D.T., MULLER, R.D., SMITH, W.H., GARCIA, E. \& FRANCIS, R. (2014) Marine Geophysics. New Global Marine Gravity Model from Cryosat-2 and Jason-1 Reveals Buried Tectonic Structure. Science, 346, 65-67.

SCHLICH, R., (1982), The Indian Ocean: Aseismic ridges, spreading centers, and basins, In: The Ocean Basins and Margins, Volume 6: The Indian Ocean, eds. Nairn, A. E. M., Stehli, F. G. 51-147, Plenum, New York, 1982.

SMITH, A. G., \& HALlAM, A., 1970, The fit of the southern continents, Nature, 225, 139144.STOREY, M., MAHONEY, J. J. \& SAUNDERS, A. D. (1997), Cretaceous basalts in Madagascar and the transition between plume and continental lithosphere mantle sources, In: Large Igneous provinces: Continental, Oceanic, and Planetary Flood Volcanism, 95-122, eds Mahoney, J.J. \& Coffin,M., Am. Geophys. Union, Monogr,Washington, DC

TORSVIK, T. H., AMUNDSEN, H., HARTZ, E. H., CORFU, F., KUSZNIR, N., GAINA, C., DOUBROVINE, P. V., STEINBERGER, B., ASHWAL, L. D. \& JAMTVEIT, B. (2013), A Precambrian microcontinent in the Indian Ocean, Nat. Geosci., 6(3), 223-227.

This article is protected by copyright. All rights reserved. 
TUCK-MARTIN, A. L., ADAM, J. \& EAGLES, G. (2016) A Tectono-Stratigraphic Framework for the East African Sedimentary Basins, PETEX - Petroleum Geoscience Collaboration Showcase Abstr. Vol., p. 50.

TUCK-MARTIN, A. L., ADAM, J. \& EAGLES, G. (2015) Correlating tectono-stratigraphic events along the East African Margin: Combining high-resolution plate kinematic models, platescale stress simulations and regional sedimentary basin fill histories. The $14^{\text {th }}$ HGS/PESGB Conference on African E\&P Abstr. Vol., pp. 125 - 126.

TURNER, J., FOUM, A. \& KUSZNIR, N. (2016) Structure of syn-breakup mini-basins, offshore Tanzania and Kenya. The Roberts Conference - Passive Margins Abstr. Vol., 77

VAN HINSBERGEN, D. J. J., STEINBERGER, B., DOUBROVINE, P. V. \& GASSMÖLLER, R. (2011), Acceleration and deceleration of India-Asia convergence since the Cretaceous: Roles of mantle plumes and continental collision, J. Geophys. Res., 116(B6), B06101.

WATTS, A. (2001), Gravity anomalies, flexure and crustal structure at the Mozambique rifted margin, Mar. Pet. Geol., 18(4), 445-455.

WESSEL, P., SMITH, W. H. F., SCHARROO, R., LUIS, J. F. \& WOBBE, F. (2013) Generic Mapping Tools: Improved version released, EOS Trans. AGU, 94, 409-410, 2013.

WHITE, R. \& MCKENZIE, D. (1989), Magmatism at rift zones: The generation of volcanic continental margins and flood basalts, J. Geophys. Res., 94(B6), 7685.

WICHURA, H., BOUSQUET, R., OBERHÄNSLI, R., STRECKER, M. R. \& TRAUTH, M. H. (2011), The Mid-Miocene East African Plateau: a pre-rift topographic model inferred from the emplacement of the phonolitic Yatta lava flow, Kenya, Geol. Soc. London, Spec. Publ., 357(1), 285-300.

WILLIAMS, S.E., WHITTAKER, J.M., \& MÜLLER, R.D. (2011), Full fit, palinspastic reconstruction of the conjugate Australian Antarctic margins, Tectonics, 30, TC6012, doi:10.1029/2011TC002912.

WOPFNER, H. (1994), The Malagasy Rift, a chasm in the Tethyan margin of Gondwana, J. Southeast Asian Earth Sci., 9(4), 451-461.

Figure 1: Overview of the present day Northwest Indian Ocean and key features. CIR - Central Indian Ridge; SEIR - Southeast Indian Ridge; SWIR - Southwest Indian Ridge; Mad - Madagascar; Afr - Africa; Ind - India; S - Seychelles; SM - Salha de Maya Bank; NB - Nazareth Bank; EARS East African Rift System; S.F. - Seagap Fault; BH - Beira High; MCP - Mozambique Coastal Plains; Karoo LIP (Jourdan et al., 2005); (CP) shaded area - Diffuse "Capricorn Plate" (Royer \& Gordon, 1997). Inset: Present day plate boundaries.

Figure 2: (a) Coloured symbols: magnetic anomaly isochron picks (see key for chron names). Rotated magnetic anomaly picks appear as grey outlines. Black triangles: fracture zone picks from gravity. Blue lines: synthetic flowlines, with white dots at each constrained time. Thick grey line: present-day ridge crest (SWIR). In the background is the vertical gradient from Sandwell et al.'s (2014) satellite gravity data set. (b) locations of the rotation poles and their $95 \%$ confidence ellipses. As for the isochron picks, not all poles are labelled to aid clarity. (c) Plot of the spreading directions in degrees clockwise from north (blue line), and the spreading rates in $\mathrm{km}$ per million years (red line) between Africa/Madagascar and Antarctica.

Figure 3: Magnetic isochron models for five profiles crossing the West Somali Basin. The profiles are all aligned on the proposed extinct median valley (Phethean et al., 2016). Model spreading stops at the end of chron M10Nn.2r (134.98 Ma in Gradstein et al. (2004)). Field inclinations are appropriate for the present-day latitude of the West Somali Basin and a paleo-latitude of $40^{\circ} \mathrm{S}$.

Figure 4: Plate outlines or isochrons used for the kinematic reconstructions. Only outlines every 10 million years are shown for clarity. (Outlines for Africa in the Atlantic Ocean come from Pérez-Díaz

This article is protected by copyright. All rights reserved. 
\& Eagles, 2014). Afr - Africa; Arb - Arabia; Ind - India; Mad - Madagascar; S - Seychelles; SL Sri Lanka; Ant - Antarctica; S.Am - South America.

Figure 5: Plate reconstruction maps showing the main stages of development in Phase 1. East Gondwana (including Madagascar/India/Antarctica/Seychelles) and West Gondwana (including Africa/South America) separated, accommodated by rifting and subsequent seafloor spreading in the West Somali and Mozambique Basins. All maps use present day bathymetry data and the Mercator projection with Africa fixed in its present-day location. (a) Fully reassembled fit of all the plates in this study to their positions within the Gondwana supercontinent 183-177 Ma, with possible maximum extent of Karoo-Ferrar LIP (Riley et al., 2006), (b) 175 Ma during continental rifting, (c) $165 \mathrm{Ma}$ just after breakup, with onset of seafloor spreading in West Somali and Mozambique Basins, (d) $150 \mathrm{Ma}$, established seafloor spreading. Afr - Africa; Mad - Madagascar; S - Seychelles; Ind India; Ant - Antarctica; S.L. - Sri Lanka; WSB - West Somali Basin; MB - Mozambique Basin; DFZ - Davie Fracture Zone; DWR - Davie Walu Ridge; BH - Beira High; MCP - Mozambique Coastal Plains.

Figure 6: Plate reconstruction maps showing the main stages of development in Phase 2. Seafloor spreading ceased in the West Somali Basin, the boundary relocated to the south of Madagascar separating Madagascar/India and Antarctica. (a) 133 Ma: onset of phase 2. Seafloor spreading has ceased in the West Somali Basin, relocated to western Enderby Basin, (b) 100 Ma: established phase 2. Afr - Africa; Mad - Madagascar; S - Seychelles; Ind - India; Ant - Antarctica; S.L. - Sri Lanka; WSB - West Somali Basin; MB - Mozambique Basin; DFZ - Davie Fracture Zone; DWR - Davie Walu Ridge; BH - Beira High; MCP - Mozambique Coastal Plains; RLS - Riiser Larsen Sea; GR Gunnerus Ridge; EnB - Enderby Basin; WEnB - West Enderby Basin; MozP - Mozambique Plateau; MadP - Madagascar Plateau; C.Is - Comoros Islands

Figure 7: Plate reconstruction maps showing the main stages of development in Phase 3. Seafloor spreading on the Mascarene Ridge opened the Mascarene Basin and separated India and Madagascar. (a) $89 \mathrm{Ma}$ Onset of phase 3, arrival of Marion plume and eruption of Morondava volcanics on Madagascar before breakup between India and Madagascar, (b) 75 Ma Established spreading in the Mascarene Basin, (c) 63 Ma Rotation of Seychelles microplate. Afr - Africa; Mad - Madagascar; S Seychelles; Ind - India; Ant - Antarctica; S.L. - Sri Lanka; WSB - West Somali Basin; MB Mozambique Basin; LB - Laxmi Basin; DFZ - Davie Fracture Zone; DWR - Davie Walu Ridge; BH - Beira High; MCP - Mozambique Coastal Plains; RLS - Riiser Larsen Sea; GR - Gunnerus Ridge; EnB - Enderby Basin; WEnB - West Enderby Basin; MozP - Mozambique Plateau; MadP Madagascar Plateau; C.Is - Comoros Islands; SWIR - Southwest Indian Ridge; SEIR - Southeast Indian Ridge; RTJ - Rodriguez Triple Junction; MasR - Mascarene Ridge; MasB - Mascarene Basin; MasP - Mascarene Plateau; SM - Salha de Maya Bank; NB - Nazareth Bank; AmT - Amirante Trench; CR - Carlsberg Ridge; CIR - Central Indian Ridge.

Figure 8: Plate reconstruction maps showing the main stages of development in Phase 4. Seafloor spreading ended in the Mascarene Basin, spreading on the Carlsberg and Central Indian Ridges separated India and the Mascarene Plateau. (a) 60 Ma Spreading on the Carlsberg Ridge, end of spreading on the Mascarene Ridge and abandonment of Seychelles plate, (b) 55 Ma Spreading on Carlsberg Ridge and Central Indian Ridge, (c) 33 Ma Mature / established spreading on Carlsberg and Central Indian Ridges. Afr - Africa; Mad - Madagascar; S - Seychelles; Ind - India; Ant Antarctica; S.L. - Sri Lanka; WSB - West Somali Basin; MB - Mozambique Basin; LB - Laxmi Basin; DFZ - Davie Fracture Zone; DWR - Davie Walu Ridge; BH - Beira High; MCP Mozambique Coastal Plains; RLS - Riiser Larsen Sea; GR - Gunnerus Ridge; EnB - Enderby Basin; WEnB - West Enderby Basin; MozP - Mozambique Plateau; MadP - Madagascar Plateau; C.Is Comoros Islands; SWIR - Southwest Indian Ridge; SEIR - Southeast Indian Ridge; RTJ - Rodriguez Triple Junction; MasR - Mascarene Ridge; MasB - Mascarene Basin; MasP - Mascarene Plateau; SM - Salha de Maya Bank; NB - Nazareth Bank; AmT - Amirante Trench; CR - Carlsberg Ridge; CIR - Central Indian Ridge; C-LR - Chagos-Laccadive Ridge.

This article is protected by copyright. All rights reserved. 
Figure 9: Chronostratigraphic diagram correlating the main tectonic phases derived from the plate kinematic model, regional tectonic events and megasequences along the East African and conjugate West Madagascan margin segments.

Table 1: Finite rotations modelled from the flanks of the Southwest Indian Ridge, Mozambique and West Somali basins, and Riiser-Larsten Sea for reconstruction of African plate with respect to East Antarctic plate. All rotations right-handed. Azimuth refers to the orientation of the $95 \%$ confidence ellipsoid in degrees anticlockwise of east. Only 95\% confidence ellipses (axes 1 and 2 and azimuth) are depicted in Fig. 2. CNS - Cretaceous Normal polarity Superchron; WSB - West Somali Basin extinction; AAM - African-Antractic Margin separation.

Table 2: Summary of the 4 phases of tectonic development of the Northwest Indian Ocean and their corresponding figures

\begin{tabular}{|c|c|c|c|c|c|c|c|c|}
\hline \multicolumn{3}{|c|}{ Finite rotation parameters } & \multicolumn{4}{|c|}{ 95\% confidence ellipsoid } & \multirow[b]{2}{*}{ Chron } & \multirow{2}{*}{ Age } \\
\hline longitude & latitude & angle & Axis 1 & Axis 2 & Axis 3 & Azimuth & & \\
\hline 136.68 & -7.46 & 0.44 & 1.37 & 0.16 & 0.02 & 39.38 & $2 \mathrm{Ay}$ & 2,581 \\
\hline 138.59 & -8.29 & 1.43 & 3.96 & 0.93 & 0.03 & 40.31 & $5 y$ & 9.786 \\
\hline 140.62 & -9.73 & 2.80 & 2.18 & 0.48 & 0.05 & 41.08 & $6 y$ & 18.748 \\
\hline 138.79 & -12.26 & 3.81 & 1.49 & 0.36 & 0.06 & 40.32 & $8 \mathrm{y}$ & 25.099 \\
\hline 135.19 & -17.17 & 5.52 & 0.93 & 0.22 & 0.04 & 41.34 & $13 y$ & 33.147 \\
\hline 136.13 & -14.19 & 6.89 & 0.89 & 0.21 & 0.05 & 44.73 & $18 \mathrm{y}$ & 38.615 \\
\hline 137.15 & -13.18 & 7.55 & 1.29 & 0.26 & 0.04 & 48.61 & $20 y$ & 42.301 \\
\hline 134.78 & -14.75 & 8.42 & 0.90 & 0.19 & 0.04 & 49.20 & $21 y$ & 45.724 \\
\hline 138.74 & -9.08 & 10.01 & 0.96 & 0.18 & 0.03 & 51.75 & $24 y$ & 52.62 \\
\hline 137.73 & -3.52 & 10.41 & 1.70 & 0.32 & 0.02 & 36.60 & $26 y$ & 58.959 \\
\hline 137.71 & 0.96 & 11.00 & 1.49 & 0.20 & 0.03 & 45.44 & 280 & 63.494 \\
\hline 136.48 & 0.98 & 11.68 & 1.13 & 0.15 & 0.05 & 50.48 & $30 y$ & 66.398 \\
\hline 136.79 & 1.52 & 12.89 & 0.93 & 0.12 & 0.05 & 50.39 & $32 \mathrm{y}$ & 71.449 \\
\hline 137.36 & 1.46 & 13.82 & 0.77 & 0.10 & 0.04 & 50.19 & $33 y$ & 74.309 \\
\hline 137.87 & -0.19 & 15.59 & 0.54 & 0.08 & 0.03 & 49.19 & 330 & 79.54 \\
\hline 140.42 & 0.12 & 17.65 & 0.28 & 0.05 & 0.03 & 49.55 & $34 y$ & 83.64 \\
\hline 142.61 & -2.85 & 27.15 & 0.19 & 0.07 & 0.02 & 46.12 & ma96 & 100 \\
\hline 143.65 & -1.20 & 36.49 & 0.19 & 0.14 & 0.02 & 53.83 & CNS & 119 \\
\hline 143.53 & -0.07 & 38.87 & 0.21 & 0.04 & 0.03 & 45.22 & M0r & 124.61 \\
\hline 144.27 & 1.52 & 41.27 & 0.21 & 0.04 & 0.02 & 45.11 & M5n & 130.8 \\
\hline 144.55 & 1.90 & 42.37 & 0.27 & 0.05 & 0.03 & 46.64 & M9n & 133.14 \\
\hline 145.22 & 3.06 & 43.34 & 0.27 & 0.13 & 0.06 & 44.23 & WSB & $133.9-133.5$ \\
\hline 145.55 & 3.22 & 44.13 & 0.11 & 0.03 & 0.03 & 36.94 & M11n & 136.44 \\
\hline 145.38 & 2.87 & 46.31 & 0.09 & 0.03 & 0.02 & 36.34 & M16n & 142.06 \\
\hline
\end{tabular}

This article is protected by copyright. All rights reserved. 


\begin{tabular}{|l|l|l|l|l|l|l|l|l|}
\hline 145.06 & 2.45 & 48.02 & 0.10 & 0.03 & 0.03 & 31.71 & M19n & 145.95 \\
\hline 145.66 & 3.14 & 50.19 & 0.13 & 0.04 & 0.03 & 28.24 & M22n & 150.21 \\
\hline 146.62 & 4.38 & 52.09 & 0.14 & 0.04 & 0.03 & 32.35 & M25n & 154.37 \\
\hline 145.77 & 6.57 & 56.27 & 0.57 & 0.07 & 0.06 & 33.27 & AAM & $183-177$ \\
\hline
\end{tabular}

\begin{tabular}{|c|c|c|c|}
\hline Phase & Age & Tectonic Events & Figures \\
\hline 1 & $\begin{array}{l}183-177 \mathrm{Ma} \\
\text { to } \sim 133 \mathrm{Ma}\end{array}$ & $\begin{array}{l}\text { Rifting, breakup and drift of } \\
\text { East Gondwana (comprising } \\
\text { Madagascar/India/Antarctica/Se } \\
\text { ychelles) and West Gondwana } \\
\text { (comprising Africa/South } \\
\text { America) accommodated by } \\
\text { seafloor spreading in the West } \\
\text { Somali and Mozambique basins }\end{array}$ & $\begin{array}{l}5 \text { (a). FIT183-177 Ma: All plates } \\
\text { reassembled within the Gondwana } \\
\text { supercontinent } \\
5 \text { (b). } 175 \text { Ma: Main rift phase } \\
5 \text { (c). } 165 \text { Ma: Breakup } \\
5 \text { (d). } 150 \text { Ma: Mature/established } \\
\text { seafloor spreading in the West Somali } \\
\text { and Mozambique Ocean Basins }\end{array}$ \\
\hline 2 & $\begin{array}{l}\sim 133 \mathrm{Ma} \text { to } \\
89 \mathrm{Ma}\end{array}$ & $\begin{array}{l}\text { Rifting and seafloor spreading } \\
\text { on the Mascarene Ridge, } \\
\text { opening of the Mascarene Basin } \\
\text { and separation of India and } \\
\text { Madagascar. }\end{array}$ & $\begin{array}{l}6 \text { (a). } 133 \text { Ma: boundary reorganisation } \\
\text { phase (seafloor spreading ends in } \\
\text { WSB) } \\
6 \text { (b). } 100 \mathrm{Ma} \text { : established phase } 2 \\
\text { seafloor spreading }\end{array}$ \\
\hline 3 & $\begin{array}{l}89 \text { Ma to } \sim 60 \\
\mathrm{Ma}\end{array}$ & $\begin{array}{l}\text { Rifting and subsequent seafloor } \\
\text { spreading on the Mascarene } \\
\text { Ridge, opening of the } \\
\text { Mascarene Basin and separation } \\
\text { of India and Madagascar }\end{array}$ & $\begin{array}{l}7 \text { (a). } 89 \text { Ma: boundary reorganisation } \\
\text { phase (extension to spreading in } \\
\text { Mascarene Basin) } \\
7 \text { (b). } 75 \text { Ma: established spreading in } \\
\text { Mascarene Basin } \\
7 \text { (c). } 63 \text { Ma: Laxmi basin opening and } \\
\text { Seychelles microplate rotation }\end{array}$ \\
\hline 4 & $\begin{array}{l}\sim 60 \mathrm{Ma} \text { to } \\
\text { present day }\end{array}$ & $\begin{array}{l}\text { Cessation of spreading on the } \\
\text { Mascarene Ridge, spreading on } \\
\text { the Carlsberg and Central Indian } \\
\text { Ridges separating India and the } \\
\text { Mascarene Plateau. }\end{array}$ & $\begin{array}{l}8 \text { (a). } 60 \text { Ma: early spreading on the } \\
\text { Carlsberg Ridge } \\
8 \text { (b). } 55 \text { Ma: established spreading } \\
\text { along the Carlsberg ridge } \\
8 \text { (c). } 33 \text { Ma: mature/established } \\
\text { seafloor spreading on the Carlsberg and } \\
\text { Central Indian Ridges }\end{array}$ \\
\hline
\end{tabular}

This article is protected by copyright. All rights reserved. 


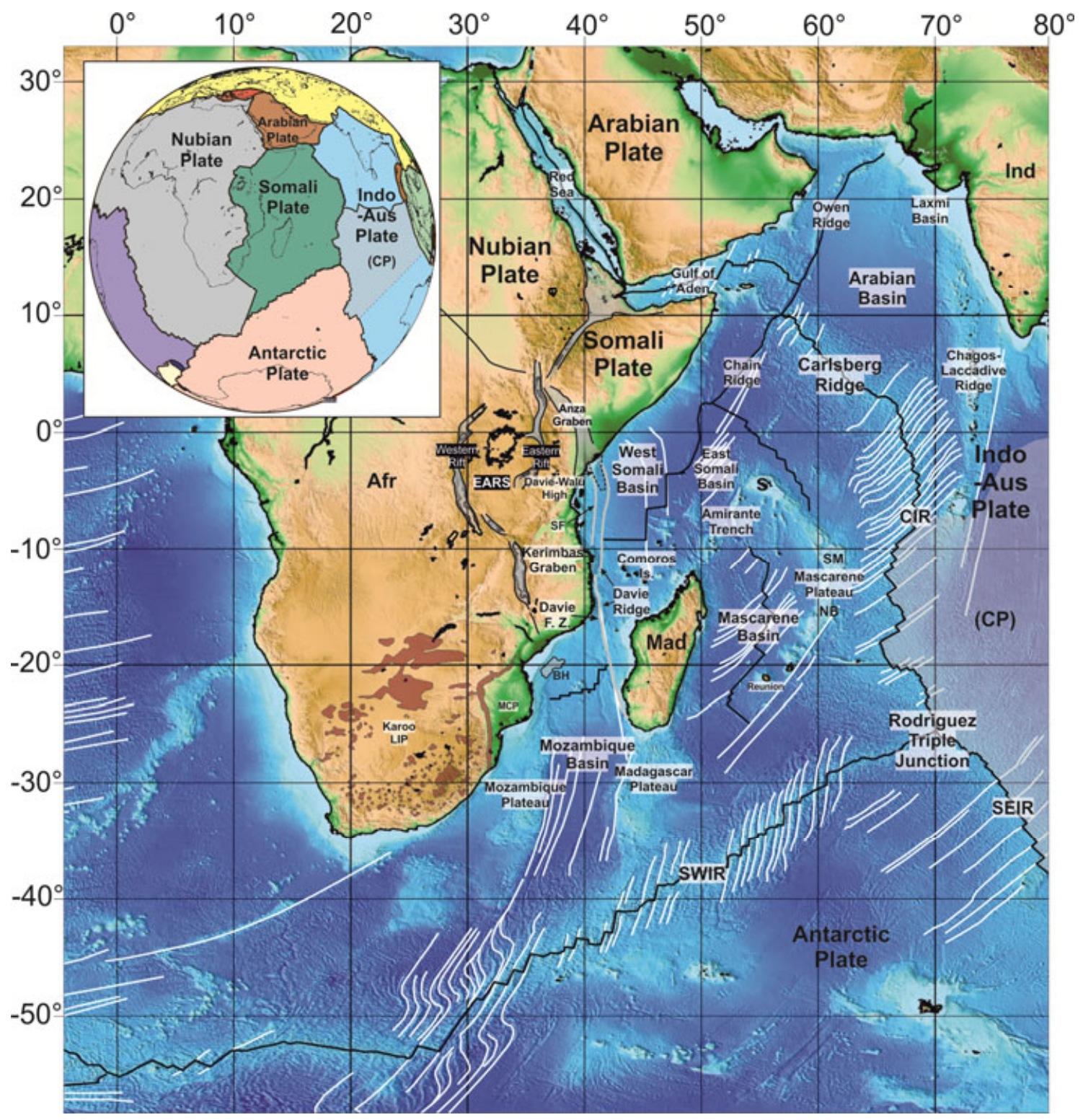

This article is protected by copyright. All rights reserved. 

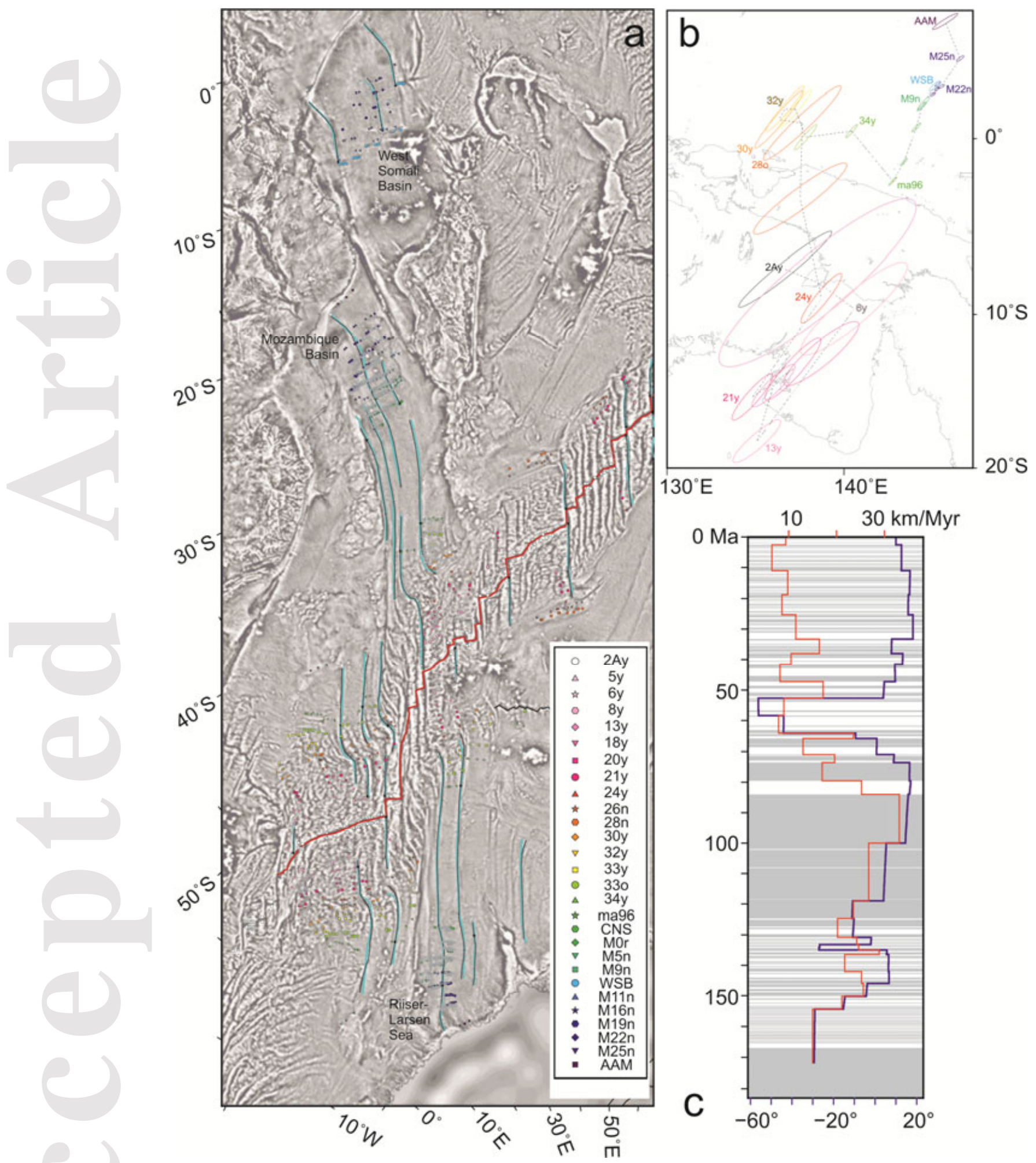

This article is protected by copyright. All rights reserved. 


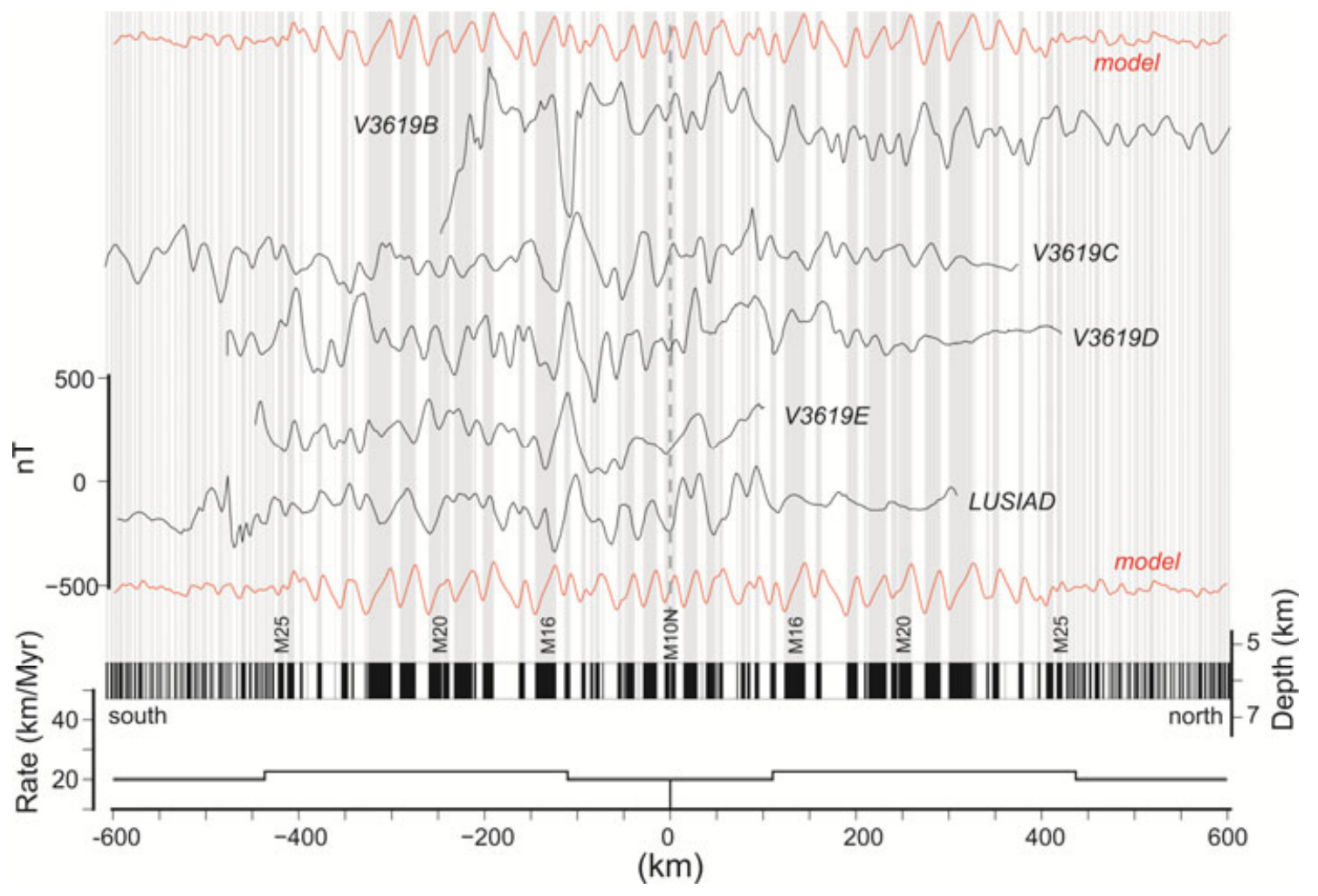

This article is protected by copyright. All rights reserved. 


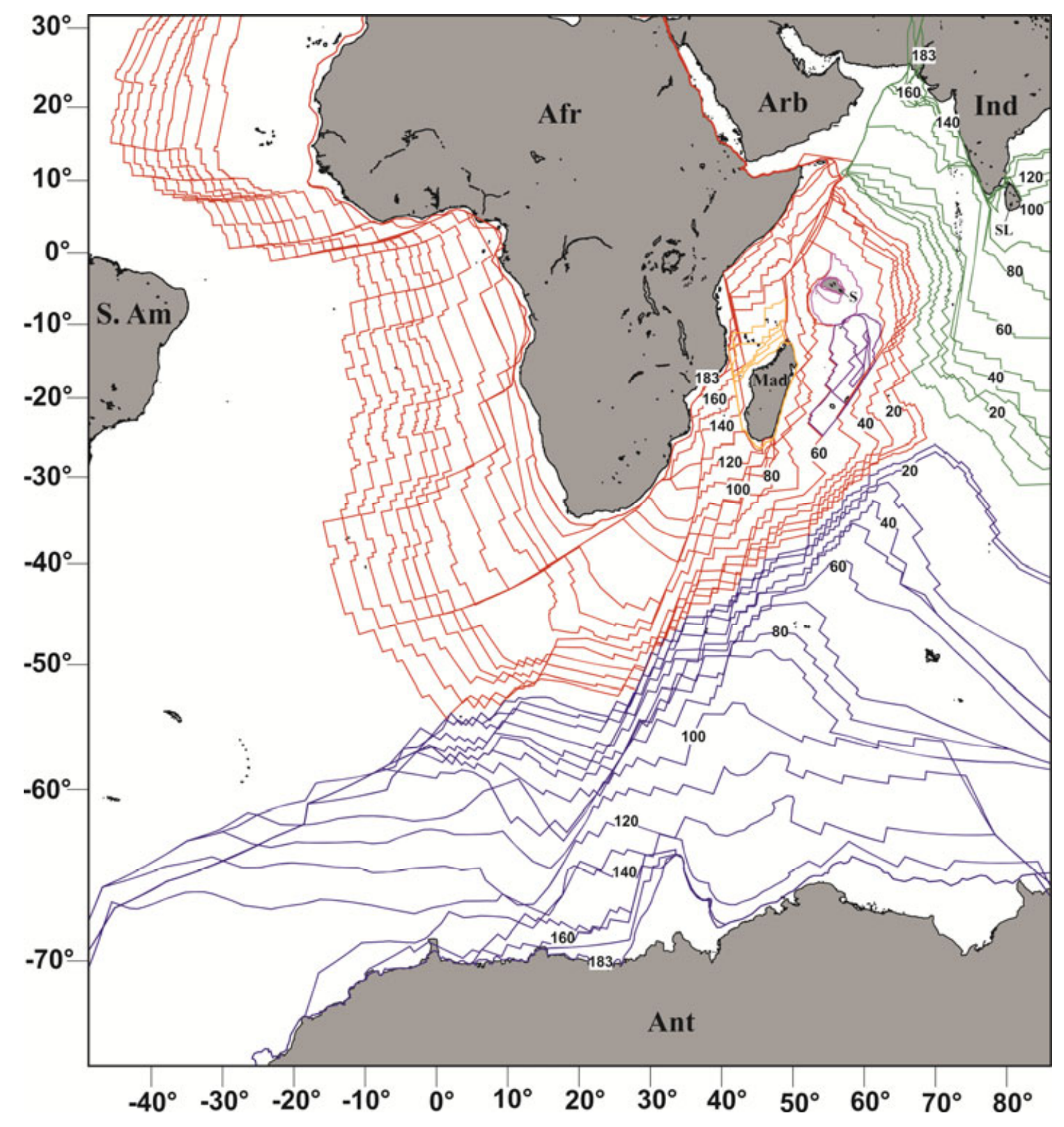

This article is protected by copyright. All rights reserved. 

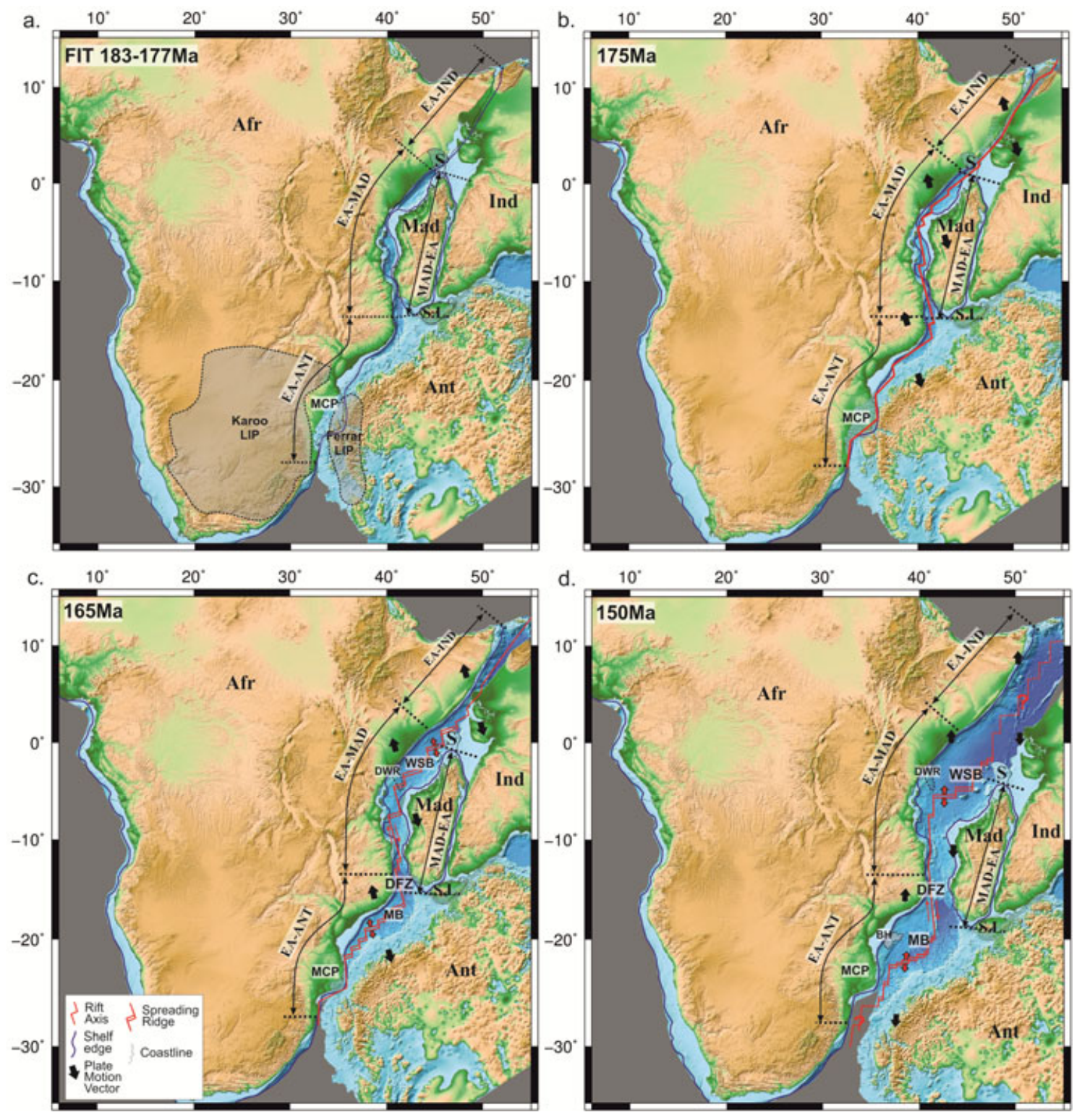

This article is protected by copyright. All rights reserved. 


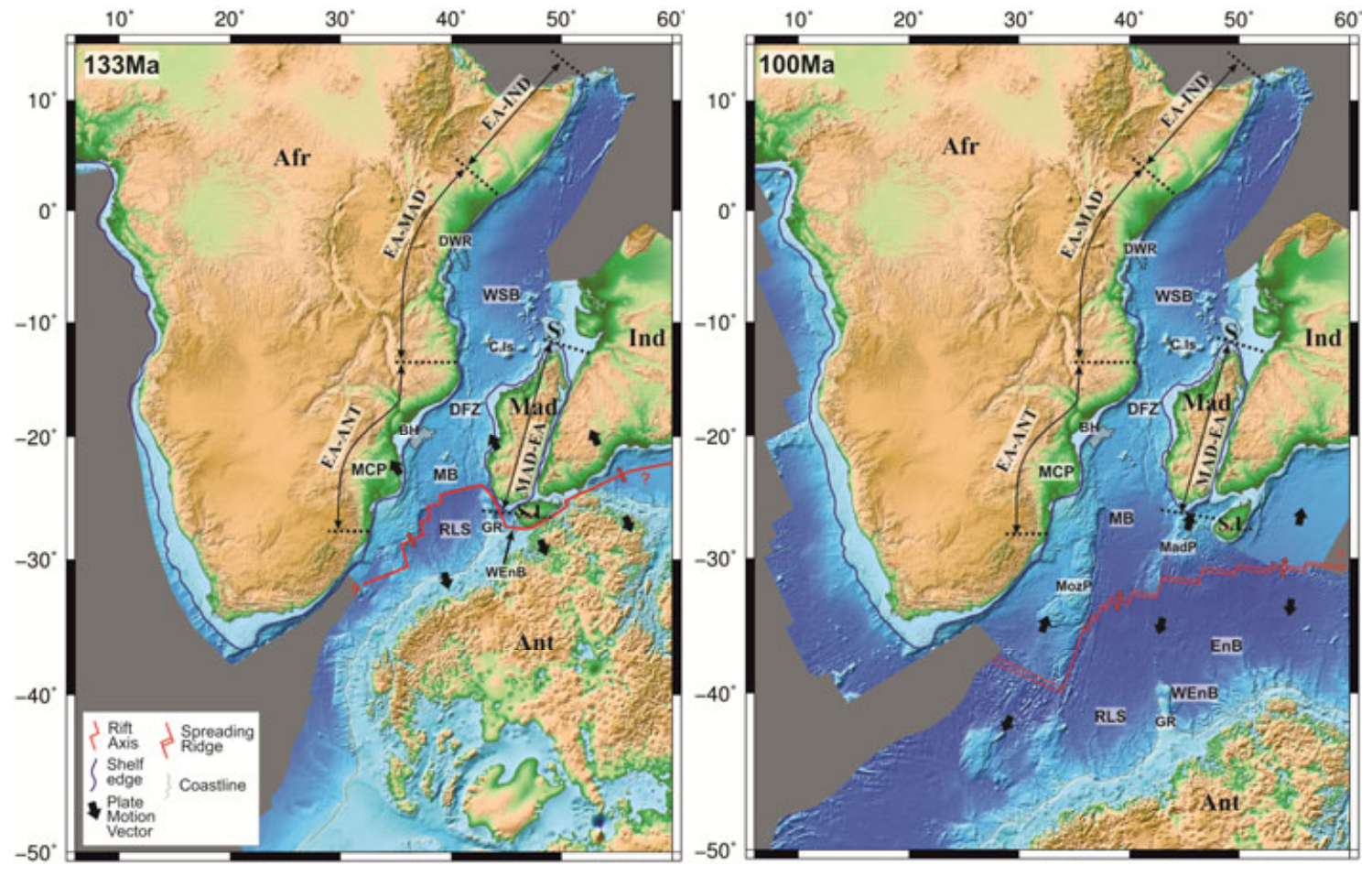

This article is protected by copyright. All rights reserved. 

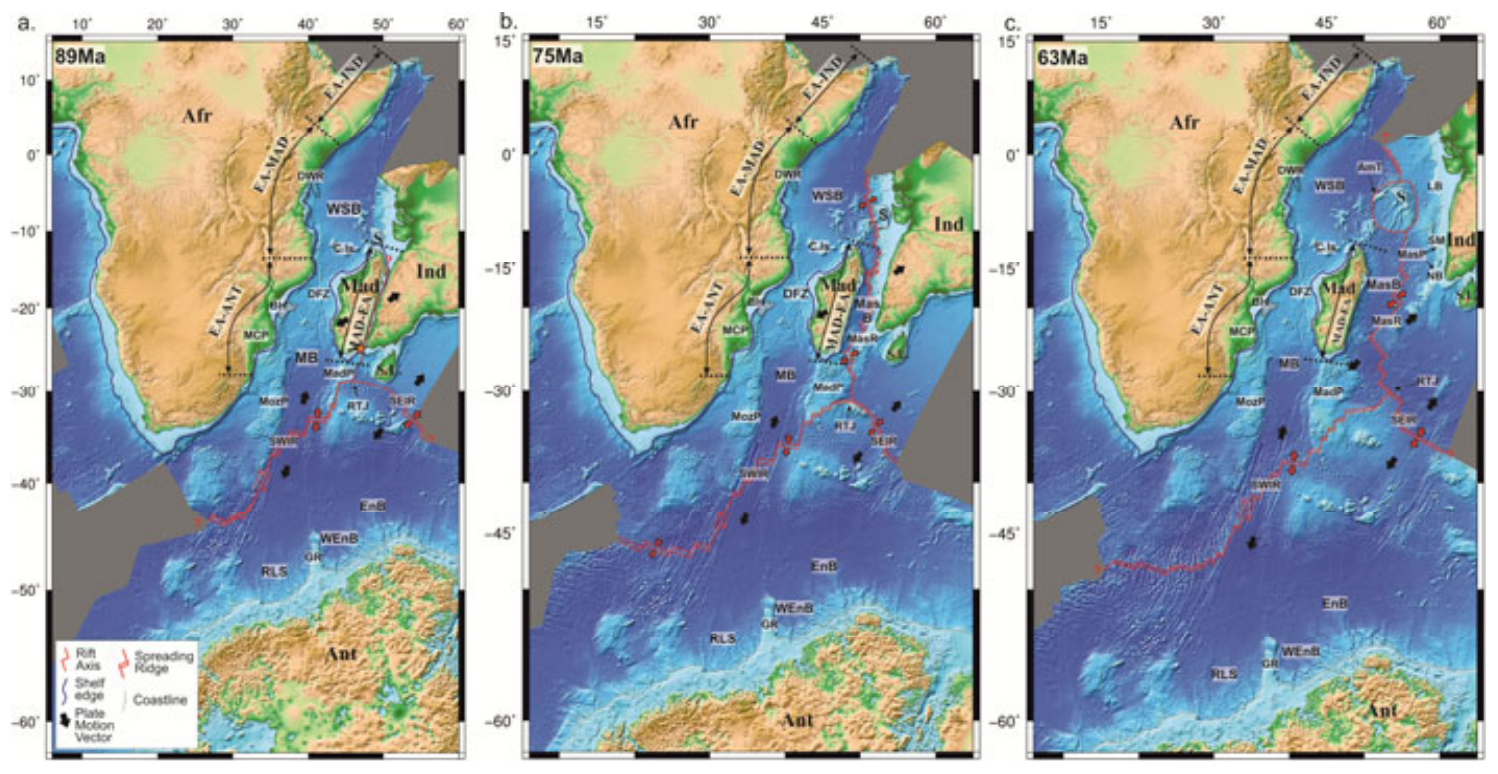

This article is protected by copyright. All rights reserved. 


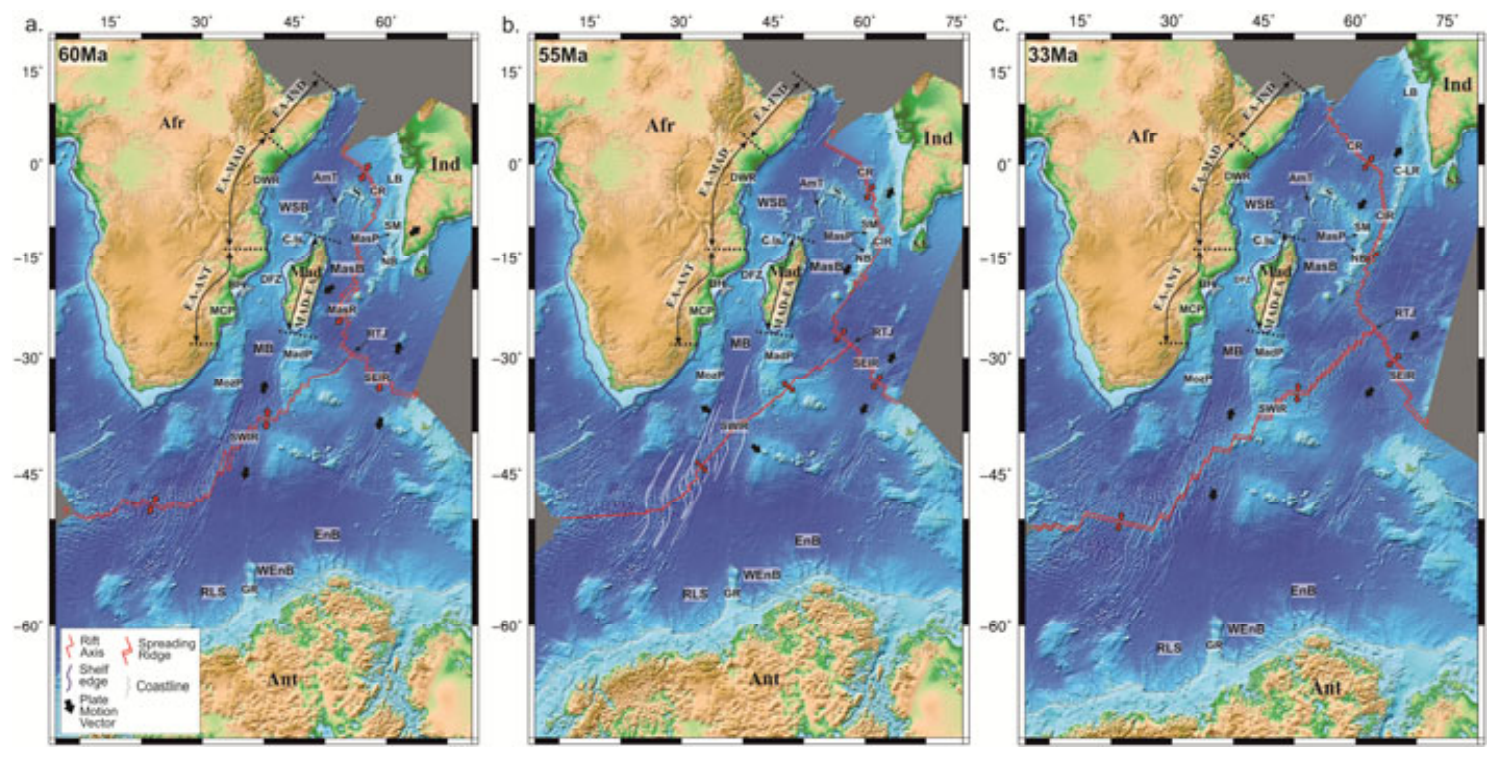

This article is protected by copyright. All rights reserved. 


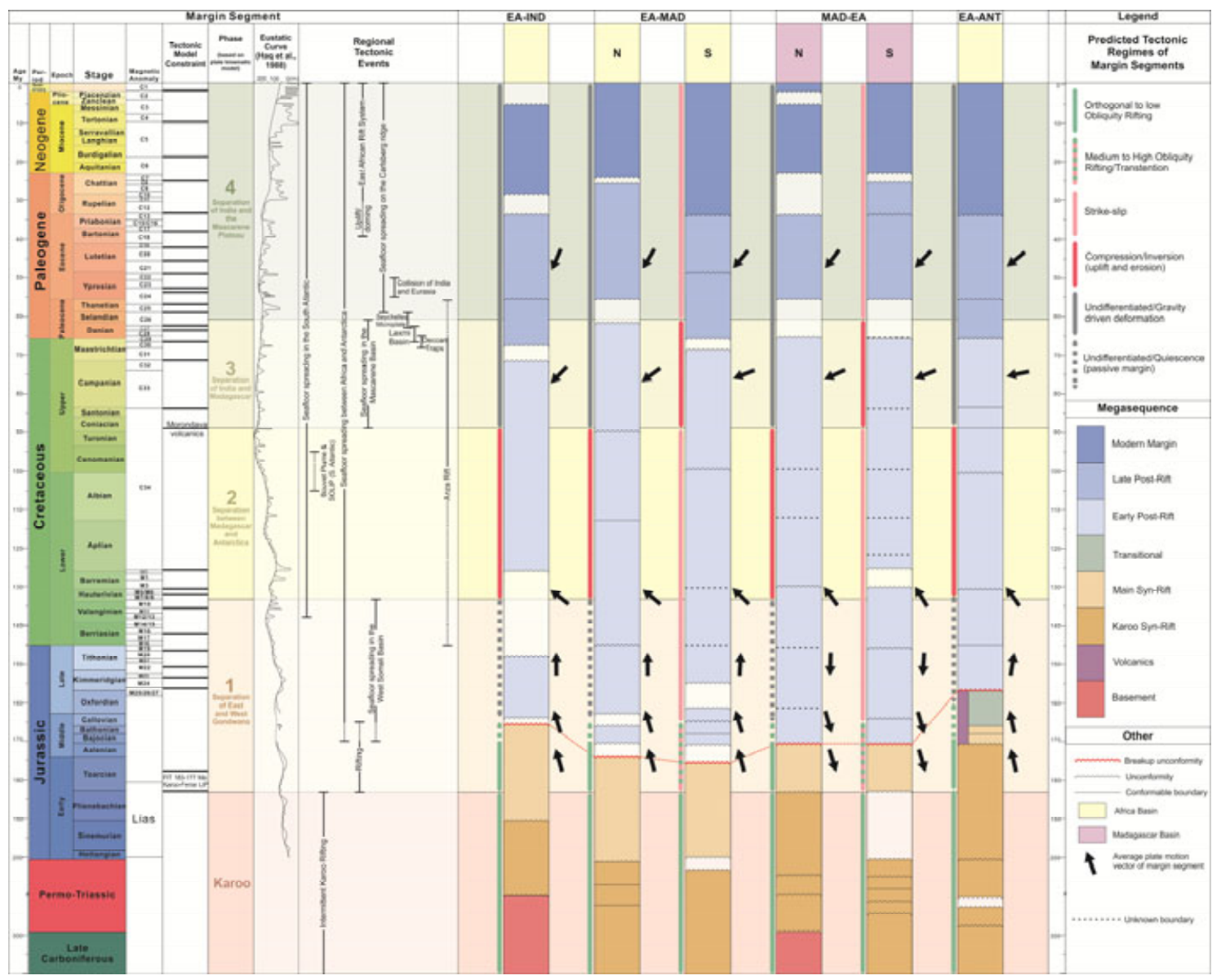

This article is protected by copyright. All rights reserved. 